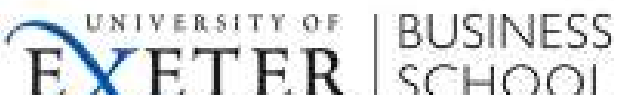 \\ XTER SCHOOL
}

\section{Pension Funding Constraints and Corporate Expenditures}

by

\author{
Weixi Liu \\ W.Liu@exeter.ac.uk
}

and

Ian Tonks

I.Tonks@exeter.ac.uk

Paper No 10/02

January 2010

The authors are both from the Xfi Centre for Finance and Investment, University of Exeter, Xfi Building, Rennes Drive, Exeter, EX4 4ST. Telephone 44-1392-263461.

This paper has benefited from seminar presentations at the University of Exeter, and we are grateful for comments from David Blake and Paul Draper. Errors remain the responsibility of the authors. 


\title{
Pension funding constraints and corporate expenditures
}

\begin{abstract}
This paper examines the effect of a company's pension contributions on its dividend and investment policies. Using a sample of all FTSE350 UK listed firms with at least one defined benefit pension scheme from 2001 to 2004, we find a strong and negative relation between pension contributions and corporate dividend payments even after controlling for the correlation between funding status and unobserved investment opportunities. We find a weaker result using investment equations, where investment is negatively related to pension contributions but the relation is not statistically significant. Our results suggest a preference of financial rather than real channels for firms making balance sheet adjustments. We also examine whether the new funding requirements under the Pensions Act 2004 have had any effects on firms' pension contributions and accordingly their corporate expenditure decisions. We include additional data from 2005-2006, and find that both dividend and investment sensitivity to pension contributions is more pronounced after the introduction of the new funding requirements.
\end{abstract}

Keywords: Pension contributions, financial constraints, dividend sensitivity, investment sensitivity, Pensions Act 2004

JEL Classification: G23 


\section{Introduction}

Recent legislation in the UK (Pensions Act 1995, Pensions Act 2004) has required companies to ensure that their defined benefit pension liabilities are appropriately funded. These regulations may impose financial pressures on companies, since in the presence of financial constraints, increased pension contributions will reduce the proportion of earnings available for investments and/or dividends payable to shareholders. The well-known Modigliani-Miller theory argues that corporate expenditure decisions are unaffected by financial considerations in perfect markets, but there is a large literature focusing on balance sheet adjustments in the presence of financial constraints in imperfect markets. Pension contributions need to be considered within a firm's budget constraints, which depict the sources and uses of funds, and has a direct impact on the firm's internally generated financial resources. If pension contributions are regarded as negative cash flows, an increase in the firm's pension contributions will influence other uses of the firm's capital such as dividends or investments either because of the budget constraints if there exists an optimal leverage level of the firm or because of costly external finance. An interesting question is whether this balance sheet adjustment is more likely to take place through financial (dividend) or real (investment) channels.

This paper examines whether a company's pension contributions has any effect on its dividend and investment policies, using the sample of all FTSE350 UK listed firms with at least one defined benefit pension scheme from 2001 to 2005. Bunn and Trivedi (2005) have previously looked at this question for UK listed non-financial companies over the period 1983-2002 and established that there is a significantly negative relation between pension contributions and dividends, but only weak evidence with respect to investment, leading them to conclude that balance-sheet adjustments in the presence of increasing pension contributions are more likely to be made through financial rather than real channels. However Rauh (2006) points out that the quantity of corporate investments undertaken is likely to be related to the availability of investment opportunities, which are not observable by a researcher. He argues that the funding status of the pension scheme will reflect the financial health of the company and the extent of such unobservable investment opportunities, and should be included as a conditioning variable in the dividend and investment equations. We extend this research on dividend/investment sensitivity to pension contributions, in two ways. First we investigate whether for UK firms the relationship persists after controlling for the potential correlations between the firm's pension funding status and unobserved investment opportunities, as in Rauh (2006), making use of data 
on pension funding status, that has only become available after the introduction of FRS17 transitional arrangements in 2001. Second, we examine whether the establishment of the Pension Regulator under the Pensions Act 2004, with the powers to require companies to ensure their pension liabilities are fully funded, has affected dividends and/or investments.

In the UK between 1995 and 2005, most private-sector defined benefit pension schemes were financed subject to the Minimum Funding Requirement (MFR) introduced in the Pensions Act 1995. This established a baseline ratio of pension assets compared with scheme liabilities in order to cover the pensioner benefits in the event of the scheme being wound up. Schemes below a threshold funding status were required to make up the deficit within a number of years according to legally specified formulas imposed by the Pensions Act 1995 to achieve a 100\% MFR funding level. In addition the MFR also enforced an upper bound on pension schemes to ensure that they were not overfunded. These regulations ensure that pension contributions are an exogenous variable which cannot be manipulated by the managers, and this is the key to the validity of the empirical specifications, as pension contributions can be regarded as an independent source of financial pressure different from those imposed by other cash flow requirements of the firm. However dissatisfaction with the operation of the MFR (Myners, 2001), caused the MFR to be replaced by a new scheme-specific funding requirement from 2005 as required by the Pensions Act 2004, and we will examine whether this new funding requirement has had an impact on the dividend and investment sensitivities.

The funding status of a pension scheme is related to both dividends and investment through its correlation with pension contributions. However Rauh (2006) argues that funding status is also related to unobserved investment opportunities of the firm through the valuation of the scheme's assets and liabilities and that this correlation does not have the same pattern as the function that links pension funding status with pension contributions ${ }^{1}$. Rauh (2006) observes that changes to the funding status of a DB pension scheme depend upon at least three factors, and each of these factors will vary cross-sectionally between firms. First, the assets of a pension scheme are usually invested in various financial securities like bonds or equity and according to FRS17 the assets 'should be measured at their fair value at the balance sheet date'. So the funding status of the scheme will be determined by the performance of these investments and a more solvent

\footnotetext{
${ }^{1}$ The relationship between pension funding status and investment opportunities is likely to be smooth, whereas the correlation between mandatory contributions and funding status is given by the legal framework, with a 'kink' at $100 \%$ funding ratio. This will be discussed in more detail in Section 3
} 
funding status will indicate better investment opportunities. Second, according to FRS17 pension scheme liabilities are measured using a projected unit method and discounted at an AA corporate bond rate, which is implicitly influenced by the overall investment performance of the market. Third, the firm's funding status is also affected by voluntary contributions it makes to the pension scheme according to the firm's own financial strength and investment performance, and so the funding status is linked to the profitability of the firm's investments. In the United Kingdom, with the increased transparency induced by retirement benefit accounting standards such as FRS17, one would be able to see this relation more clearly. Funding status constitutes a missing variable that should be included in the empirical specifications of Bunn and Trivedi (2005), so that the sensitivity of dividends and investments to pension contributions, need to be conditioned on the pension funding status.

Using a sample of FTSE350 UK listed firms with at least one defined benefit pension scheme from 2001 to 2004, we find a strong and negative relation between pension contributions and corporate dividend payments even after controlling for the correlation between funding status and unobserved investment opportunities. Moreover when replacing the total contribution variable with simulated mandatory pension contributions to capture the interaction between contributions and pension funding status, the contribution variable loses its explanatory power in contrast to the results for the US in Rauh (2006). This may be due to the different contributing rules in UK and US as well as the failure of FRS 17 valuation to capture the MFR funding status. We find a weaker set of results when applied to the investment equations, where although investment is negatively related to pension contributions, the relation is not statistically significant. Our results suggest that even after controlling for the endogeneity of pension funding status, companies appear to make balance sheet adjustments using financial rather than real channels,

In order to assess whether the funding requirements under the Pensions Act 2004 have had any effect on firms' pension contributions and accordingly on their corporate expenditure decisions, we included additional data after the introduction of the new funding requirement. We find significant differences in the slope coefficients of the pension contribution variables before and after 2005 suggesting that the corporate expenditure sensitivities to pension contributions are significantly stronger after the introduction of the Pensions Act 2004. These results indicate that dividends and investments are more sensitive to the contributions made under the Pensions Act 2004 rather than the smoothed contributions under the MFR. 
The rest of the paper proceeds as follows. Section 2 discusses in more details the theories behind corporate budget constraints and balance sheet adjustment in an imperfect market. Section 3 compares the funding requirement in US and UK and introduces the empirical specifications for dividends and investment. Section 4 presents the sample selection and descriptive statistics. Section 5 reports the empirical results. Section 6 presents the evidence from adding the more recent data after the introduction of the new funding requirement into the regressions and section 7 concludes the paper.

\section{Pension Contributions and Balance Sheet Adjustment}

According to the Modigliani-Miller theory, financing considerations are irrelevant in perfect capital markets. In the absence of taxes, asymmetric information and agency problems, the market value of any firm is independent of its capital structure. All corporate financial decisions, linking the source and use of funds, at time $t$ can be expressed as:

$$
\left(1-\tau_{\Pi}\right) \Pi_{t}+E_{t}+\Delta D_{t}=d_{t}+\left(1-\tau_{r}\right) r_{t} D_{t}+I_{t}
$$

where $\tau_{\Pi}$ is the corporate tax rate, $\Pi$ is the nominal profit, $E$ is the value of new issues or new equity, $\Delta D_{t}$ can be regarded as new bond issues or new debt raised at time $t$ so the sources of corporate expenditure (after-tax profit plus new equity issues and new bond issues) must equal the uses of those funds, expressed as the sum of dividends $(d)$, interest payable ( $r$ is the interest rate and the interest rate being reduced by $\tau_{r}$ reflects that the debt is tax-deductible) and investment $(I)$. However the stock market environment is far from perfect: the non-tax assumption is obviously violated in equation (1); it is often believed that the managers of the firms have better information than outside investors; and agency problems arise if managers act in their own interests.

If a firm's DB pension scheme is in deficit, which could either result from an unexpected increase in pension liabilities or a decrease in the value of the pension assets, the company will need to make contributions into the pension scheme from its profits. Pension contributions should be seen as a component of corporate expenditures, and need to be included into the firm's budget constraint in equation (1). Expressing the net profit after pension contributions $\left(\Gamma^{\text {Pension }}\right)$ as the gross earnings minus pension contribution $(P C)$ :

$$
\Pi_{t}^{\text {Pension }}=\Pi_{t}-P C_{t}
$$


equation (1) can be rearranged as:

$$
\left(1-\tau_{\Pi}\right) \Pi_{t}+E_{t}+\Delta D_{t}=d_{t}+\left(1-\tau_{r}\right) r_{t} D_{t}+I_{t}+(1-\tau) P C_{t}
$$

Equations (1) and (3) illustrate that when a firm faces financial pressures, balance sheet adjustments needs to be undertaken to restore the sources and uses equality. The balance sheet adjustment can take place through dividend distributions and new equity issuance, or real investments.

Assuming that gross earnings are exogenous, and also holding the company's equity and debt volumes constant, an increase in pension contribution must reduce either dividends or investment, or both. This can be easily understood by rearranging equation (3) as:

$$
d_{t}+I_{t}=(1-\tau)\left(\Pi_{t}-D_{t}\right)+E_{t}+\Delta D_{t}-(1-\tau) P C_{t}
$$

and equation (4) will serve as the fundamental specification for empirical tests in the following sections.

Myers (2001) summarises why capital structure might matters in investment decisions. His paper focuses on two alternative theories: the trade-off theory and the pecking order theory. The trade-off theory relaxes the non-tax assumption in Modigliani and Miller (1958) and predicts that since debt interest payments are usually tax-deductible, managers tend to take advantage of this tax shield until the benefit is fully offset by the possible cost of financial distress or credit down-grading caused by higher leverage. Although MacKie-Mason (1990) and Graham (1996) find some support for the trade-off theory, other work is contradictory since the theory is confronted by the finding that more profitable companies with higher credit ratings often borrow less (Rajan and Zingales, 1995; Wald, 1999; Graham, 2000). According to the trade-off theory, an increase in pension contribution should have no effect on a firm's total borrowings, as firms are already at their optimal leverage that fully exploits the corporate tax shields. Holding everything else constant, an increase in corporate expenses through higher pension contributions has to be offset by lower dividends or investment or both.

The pecking order theory is based on information asymmetries between managers and the stock market, and asserts that the financing of investments by a firm is undertaken by first using internal resources, then debt and, as a final resort, equity (Myers (1984) and Myers and Majluf (1984)). A new equity issue by managers, which would dilute current shareholders' ownership 
of the firm, therefore could be taken by potential investors as a signal that the existing stock is overvalued. Empirical studies have found support for the pecking order theory (Asquith and Mullins, 1986; Dierkens, 1991; Eckbo, 1986; and Shyam-Sunder, 1991) and some suggest it better explains the financial behaviour of the sample firms (Shyam-Sunder and Myers (1999)). As pension contributions are subtracted from profit, an increase in pension contributions will reduce the internally available funds to finance corporate expenditures. As firms prefer internal to external finance according to the pecking order theory, firms with increased pension contributions will have to reduce the dividend payment to keep the same level of internal funds for capital investment or alternatively cut their expenditures on investment as a result of lower internal funds. Even if firm turns to external finance, they will do so by borrowing and investment will be lower than otherwise to reflect the increase in the cost of capital. Tests of the pecking-order versus trade-off theories have concluded that the pecking order theory applies to large mature firms, and the trade-off-theory to small, young growth firms (Fama and French, 2002; Frank and Goyal, 2003).

As well as the corporate finance view, there are also several studies on capital structure from the tax literature. The 'new view' of dividend taxation first proposed by King (1977) and Auerbach (1979) suggests that the real investment decisions of a firm are predetermined because of differential taxation of corporate and personal income; and therefore any balance sheet adjustments are more likely to take place through financial channels such as dividends. Similar to the pecking order theory, the 'new view' predicts that firms prefer to use internally generated funds by earnings retention to fund investment rather than using externally raised equity and distribute residual funds as dividends. Auerbach and Hassett (2002) find empirical support for this theory using US data. According to the new view, an increase in pension contributions will reduce the amount of internally available funds for investment. Therefore to keep investments at their profit maximizing level, dividends will be adjusted downwards

Following Benito and Young (2007), Bunn and Trivedi (2005) apply the dynamic panel data model developed by Blundell, Bond, Devereux and Schiantarelli (1992), and Bond, Chennells and Devereux (1996), to the dividend and investment equations and estimate the effect of pension contributions on corporate expenditures. Consistent with both trade-off and pecking order theories, they find pension contributions are negatively and significantly related to both dividends and investment, although the evidence is weaker on investment, suggesting balance sheet adjustment take place through financial (dividends) rather than real (investment) channels. 
We have argued that the current funding status of a pension scheme can affect investments. Rauh (2006) considers the endogeneity between funding status and investment in a US context and by dividing firm cash flows into pension- and non-pension-related components, he finds that the negative relation between capital expenditure and pension contributions still holds even when controlling for the correlations between the pension funding status and the firm's unobserved investment opportunities. However it may be argued that these effects may not be symmetric for overfunded (the fair value of scheme assets is greater than the fair value of liabilities) and underfunded (the fair value of scheme assets is less than the fair value of liabilities) schemes, both because of the limits imposed on scheme overfunding (discussed in the next section) and because managers could anticipate the gains from a surplus in the pension plan due to short termism and adjust corporate expenditures accordingly (Gross, 1995; Franzoni and Marin, 2006).

\section{Regulatory Funding Requirements and Empirical Specifications}

In this section we first present the relevant regulations for pension contributions by comparing the funding requirement in US and UK, and we then examine the implications of these regulations for the empirical specifications for dividends and investment models and the choice of econometric techniques that best fit the data and the model.

\section{i. $\quad$ Pension Funding Requirements in US and UK}

In US the calculation of pension contribution are based on both SEC (Securities and Exchange Commission) and IRS (Internal Revenue Service) form 5500 filings. Langbein and Wolk (2000) provide a detailed guideline on pension and employee benefits in the US. Generally speaking, firms with underfunded pension schemes are required to make contributions equal to the new benefits accrued during the previous year plus a fraction of the funding shortfall whilst firms with overfunded plans do not have to make contributions but the extent to which a scheme can be overfunded is limited by maximum deductibility laws to prevent firms from deliberately increasing pension plan surplus by reducing employee benefits.

Under the US pension law, firms with defined benefit pension plans are required to make contributions according to either minimum funding contribution (MFC) or the deficit reduction 
contribution (DRC) rule, whichever is larger. The former was first introduced in 1974 by the Employee Retirement Income Security Act (ERISA) which established the minimum funding standards for most voluntary pension and health plans in the private industry. According to MFC, firms must make annual contributions equal to the cost of benefits earned during the year ('normal cost') and any unfunded shortfalls in the plan (which may be amortised) in order to maintain a "funding standard account". The DRC is the contribution established to reduce the shortfall of the plan until the funding status reaches some threshold level, in which the plan assets are between $80 \%$ and $90 \%$ of the current liabilities of the plan (i.e. $80 \%$ to $90 \%$ funded).

Funding requirement in US were changed though the Pension Protection Act (PPA) which came into effect in 2008. The new PPA rules apply differently to single- and multi-employer plans. The funding requirement for single-employer plan is simply that a plan must stay fully funded (i.e. plan assets equal or exceed its liabilities). If a plan is fully funded, the minimum required contribution is the cost of benefits earned during the year. The contribution will also include the amount necessary to amortize the deficit over seven years if a plan is not fully funded and stricter rules will apply to severely underfunded plans or plans in 'at-risk status'. For multiemployer pension plans, most of the pre-PPA funding rules will apply but the amortization period for benefit improvements will be shortened.

The British system of funding for DB pension plans is similar but was established later than its US counterpart, and only after the debacle of the Maxwell scandal of 1991. As a part of the Pensions Act 1995, the Minimum Funding Requirement (MFR) was introduced from April 1997 and applies to most private-sector defined benefit pension schemes. MFR sets its own methods for calculating the funding status of defined benefit schemes and is operated in a similar way to the DRC mentioned above. For a scheme which has a funding level less than $90 \%$ the sponsor has to make up the shortfall below $90 \%$ within three years whereas for schemes between $90 \%$ and $100 \%$ funded the shortfall has to be paid off over a period not to exceed ten years. The detailed methods and assumptions for minimum funding valuation were specified in Guidance Note 27 issued by the Institute of Actuaries and the Faculty of Actuaries and a summary can be found in Davis (2000). The Pensions Act 1995 also enforces a limit for scheme overfunding, where schemes more than $105 \%$ funded have to reduce the surplus by benefit improvement or contribution decrease. 
However the MFR was heavily criticised by Myners (2001). First in a number of cases, the level of assets required by the MFR proved insufficient to provide the benefits promised by the scheme. Second, it increased the regulatory costs for sponsoring firms without delivering the level of security as expected. Third, it made firms focus on meeting the requirements of the MFR, rather than on developing an appropriate funding strategy for meeting their specific pension commitments, which hampers firms from making appropriate investment decision. The Pensions Act 2004 replaced the MFR with a new scheme funding objective allowing more flexibly to individual schemes' circumstances whilst at the same time protecting members' benefits. Pension scheme trustees have the discretion to decide on an appropriate strategy for funding their pension commitments and making up any funding deficits, given advice from the actuary. The new funding requirement does not violate the Pension Protection Fund valuation methods, as the latter is carried out separately for all participating schemes with a consistent measure in order to achieve fairness across schemes

According to Bunn and Trivedi (2005), the MFR ensured that 'an employer's contribution to pension scheme is a bounded variable which cannot be adjusted in response to the company's financial conditions... (and) ... adjusting contributions ... is clearly restricted'. They regard this fact as the key to the validity of their empirical specifications, as they argue pension contributions can be regarded as a relatively exogenous variable under the MFR.

\section{ii. Empirical Specifications}

The empirical specifications for dividend and investment follow those by Benito and Young (2007), although we choose to scale the variables by the total assets of the firm rather than sales or capital stock. ${ }^{2}$. The modified specification for dividends is

$$
\begin{aligned}
\frac{D_{i t}}{A_{i t}}= & \sum_{j=1}^{2} \alpha_{j} \frac{D_{i t-j}}{A_{i t-j}}+\alpha_{3} \frac{I_{i t-1}}{A_{i t-1}}+\alpha_{4} \frac{C F_{i t-1}}{A_{i t-1}}+\alpha_{5} c g r_{i t-1}+\alpha_{6} b r_{i t-1} \\
& +\alpha_{7} Q_{i t-1}+\alpha_{8} \frac{P C_{i t-1}}{A_{i t-1}}+\mu X_{i t-1}+\sum_{t=2002}^{2004} \gamma_{t}^{D} \tau_{t}+\zeta_{i}^{D}+\varepsilon_{i t}^{D}
\end{aligned}
$$

where all the variables are scaled by $A$-year-end book value of total assets-where applicable, $D$ is the firm's dividend net of tax, $I$ is investment, $C F$ is cash flow, $c g r$ is the capital gearing ratio and $b r$ is the borrowing ratio. $Q$ is the Tobin's $Q, P C$ is pension contributions disclosed in

\footnotetext{
${ }^{2}$ Most of the investment literature chooses the scaling variables arbitrarily between assets and capital See for example, Kaplan and Zingales (1997, 2000), Baker, Stein and Wurgler (2003), and Rauh (2006).
} 
the profit and loss account ${ }^{3}, X$ is the controlling variables that account for the funding status of the pension scheme defined as the net deficit of the pension scheme (scaled by assets) ${ }^{4}$. The variable $\tau_{t}$ is a dummy variable that equals to 1 for year $t$ and 0 otherwise so by construction the term $\sum_{t=2002}^{2004} \gamma_{t}^{D} \tau_{t}$ standards for the common year effects in the panel regression and $\zeta_{t}$ is the company specific effect whilst $\varepsilon$ is the error term, where the subscript $D$ denotes coefficients in dividend specification. These year and company fixed effects allow for both changes in economic conditions on dividend payments, and the characteristics of some companies to be either high or low pay-out types. Note all specifications (including the dividend and investment equation) have a constant term but we choose not to report these in the empirical results.

$\alpha_{8}$ and $\mu$ are the coefficients of interest. Generally speaking, according to both trade-off and pecking order theories $\alpha_{8}$ is expected to be negative if pension contributions are treated as a 'negative' cashflow. If pension deficits have a clear anticipated contribution effect or liquidity effect on corporate expenditure and is correlated with the unobserved investment opportunities, it should be negatively related to investment or in other words, positively related to dividends, as lower investment expenditures will increase the available funds for dividend payment so $\mu$ is expected to be positive.

As previously discussed, firms prefer to finance investment through retained earnings because of asymmetric information (pecking order theory) or differential taxation ('new view' of dividend taxation) therefore firms with better investment opportunities or large investment volumes are less willing to pay dividends, which also needs to be subtracted from retained earnings. So a testable hypothesis is that $\alpha_{3}$ is negative. Since cash flow is also highly correlated with retained earnings, dividends should react positively to it, i.e. $\alpha_{4}>0$ (Auerbach and Hassett (2000)).

The capital gearing ratio (cgr) and borrowing ratio $(b r)$ proxy for the leverage level of the firm and subsequently its financial pressure. We define $b r$ to be the Nickell and Nicolitsas (1999) borrowing ratio, a proxy of general financial pressure other than pension contributions, which is calculated as net interest payment divided by pre-tax profits. The effect of debt on dividends

\footnotetext{
${ }^{3}$ Datastream item X114. Bunn and Trivedi (2005) provide the detailed rationale why this is a sensible measure of firms' pension contributions.

${ }^{4}$ So fundingstatus is negative for overfunded firms and positive for underfunded firms.
} 
(and investment) is ambiguous, as according to the trade-off theory by adjusting debt to its optimal level, investment or dividends do not need to change as the adjustment can be undertaken through the raise of new equity. However according to the pecking order theory, leverage represents the firm's need for external finance and a higher debt level could imply that the firm has less internal fund for dividend payment or investment to reflect a higher cost of capital so leverage ratio should be negatively related to corporate expenditure.

Tobin's $Q$ is defined as the ratio of the market value of a firm's assets (as measured by the market value of its outstanding stock and debt) to the replacement cost of the firm's assets. It measures the relevant performance of the firm by looking at how market values the assets and is also related to the unobserved investment opportunities of the firm. If investment is indeed negatively related to dividend payment, this would imply a negative relation between $Q$ and dividend as a higher $Q$ stands for a higher demand for investment fund (i.e. $\alpha_{7}<0$ ). However $Q$ is difficult to measure since the replacement costs of a firm's assets are often unknown, so it is common to calculate $Q$ by approximation (Chung and Pruitt, 1994). This paper follows the construction by Rauh (2006) to set $Q$ simply as the market-to-book ratio of firm assets, which is calculated as

$$
Q_{i t}=\frac{M C_{i t}+A_{i t}-\text { CommonEquity }_{i t}-\text { DeferredTax }_{i t}}{A_{i t}}
$$

where $M C$ is the market capitalisation of the firm.

The modified specification for investment is

$$
\begin{aligned}
\frac{I_{i t}}{A_{i t}}= & \sum_{j=1}^{2} \beta_{j} \frac{I_{i t-j}}{A_{i t-j}}+\beta_{3} \frac{S_{i t-1}}{A_{i t-1}}+\beta_{4} \frac{C F_{i t-1}}{A_{i t-1}}+\beta_{5} c g r_{i t-1}+\beta_{6} b r_{i t-1} \\
& +\beta_{7} Q_{i t-1}+\beta_{8} \frac{P C_{i t-1}}{A_{i t-1}}+v X_{i t-1}+\sum_{t=2002}^{2004} \gamma_{t}^{I} \tau_{t}+\zeta_{i}^{I}+\varepsilon_{i t}^{I}
\end{aligned}
$$

where $S$ is the total sales of the firm, the other variables are as previously defined in the dividend equation and the superscript $I$ represents coefficients in the investment equation. The coefficient for pension contribution $\left(\beta_{8}\right)$ should be zero according to the afore-mentioned capital structure theories but $v$ is expected to be negative due to the positive correlation between pension assets and investment. The estimates for debt level $\left(\beta_{5}\right.$ and $\left.\beta_{6}\right)$ should also have the same effect on investment as with the dividend equation. As the new explanatory variable, total sales $(S)$ is 
correlated with the current cash flow $(C F)$ thus one would expect similar patterns for the estimates of these two variables. And if $Q$ proxies unobserved investment opportunities, it should be positively related to the investment volume (i.e. $\beta_{7}>0$ )

The investment-cash flow sensitivities $\left(\beta_{4}\right)$ in the investment model should be interpreted with caution. Fazzari, Hubbard and Peterson (1988) link this sensitivity with financial constraints of the company. By making similar assumptions to the pecking order theory that external finance is more costly than internal finance due to asymmetric information, they show that greater investment-cash flow sensitivities imply firms rely more on internal funds and a larger 'information premium' on external funds, which they regard as a sign of financial constraints. However several studies have raised doubts as to the presence of financial constraints within firms having high investment-cash flow sensitivities. Kaplan and Zingales (1997) find empirical evidence against Fazzari, et al (1988) by showing that using the same sample but a different empirical methodology, less financially constrained firms exhibit significantly greater sensitivities than firms that appear more financially constrained. Some studies (e.g. Gomes (2001)) have also argued that the results by Fazzari et al (1988) lie on the strong assumption that the Tobin's $Q$ in their investment specification is a proxy for investment opportunities, which may be unrealistic in imperfect capital markets.

For both investment and dividend equations, the first and second lags of the dependent variable are included as explanatory variables. This approach allows for the persistence of the dependent variables especially for dividends, as Lintner (1956) argues that companies are reluctant to reduce dividends as firms are uncertain about the signal provided to the market by departing from the previous dividend level. This would imply a positive estimate for lagged dividends $\left(\alpha_{1}\right.$ and $\alpha_{2}$ ) and the higher the value, the higher the degree of persistence in dividend payments.

Both equations 6 and 8 are fixed effects dynamic panel data (DPD) models by construction. By including lagged dependent variables in the right-hand side, the regression errors are no longer uncorrelated with the independent variables. A general solution is to use instrumental variables and we use the generalised methods of moments (GMM) estimator proposed by Arellano and 
Bond (1991) and Arellano and Bover (1995). ${ }^{5}$. We employ the two-step robust GMM-system estimator introduced by Blundell and Bond (1998).

\section{Sample and Descriptive Statistics}

The sample consists of all firms from the FTSE350 constituent list that have at least one defined benefit pension scheme. All the company accounts data except for the pension funding status figures are taken from Thomson Financial Datastream Historical Company Accounts data (1965-2005) purchased by ESRC (Economic and Social Research Council) and the ESDS (Economic and Social Data Service) in conjunction with Datastream current datasets where applicable ${ }^{6}$. Post-2005 most financial data such as dividends and investments are replaced by data from Thomson ONE Banker. The pension funding status data are hand-collected from individual company's annual reports and accounts based on FRS17/IAS19 disclosures from 2001, the first year such disclosures are available according to FRS17, to 2004, the last year when matching data on dividends and investment are available from Datastream historical data. The full data ranges from financial year 2000 to $2007^{7}$ however as both the dividend and investment specifications have lagged dependent variables up to the second order, only these two dependent variables $\left(D / A_{t}\right.$ and $\left.I / A_{t}\right)$ cover the whole duration of the sample years and the rest of the variables are between 2001 to 2006. The size of the full sample is 935 year-end observations, on 196 individual firms.

Table 1 reports the descriptive statistics and the distribution of the variables. All variables are winsorized at $99 \%$ level to prevent any outlier effects. Panel A reports summary statistics for the data over the period 2000-2005. The mean dividend-to-asset ratio is $5.6 \%$ and the median is $4.0 \%$. Corporate expenditures on investment have an average of $6.4 \%$ over assets with median value being $5.8 \%$. The cash flow variable $(C F)$ is calculated as after-tax income plus depreciation. Normally this is the cash flow reported on income statements and it does not contain pension contribution data therefore the specification for cash flow is consistent with decomposition of corporate expenditures in equation 1 . The mean ratio of cash flow to assets is

\footnotetext{
${ }^{5}$ In this paper where both first- and second-order lagged dependent variables are included, the validity of the GMM estimators lies on the assumption that there is only first-order serial correlation within dependent variable but no second-order serial correlations in the differential equations. These assumptions are testable and results are reported in the empirical results section below.

${ }^{6}$ This is because since 2005 Datastream eliminates data that ceases to be publish in company accounts from its dataset and they are no longer to be found in the standard Datastream package..

${ }^{7}$ A financial year is defined as from 1st July in the previous year to 30th June in the following year; and therefore the data is collected up till 30/06/2008.
} 
$14.4 \%$ and the median is $14.2 \%$. The capital gearing ratio $(\mathrm{cgr})$ is taken from Datastream (item $\mathrm{x} 731)$ and the borrowing ratio $(b r)$ uses the Nickell and Nicolitsas (1999) definition, calculated as net interest payment divided by pre-tax profits. It can be seen that the borrowing ratio has an average value of $14.8 \%$ which is only half the value of the mean borrowing ratio $(31.8 \%)$ in Bunn and Trivedi (2005), who use data from all UK quoted firms. This can be explained as the firms in our sample are FTSE350 firms and are relatively larger UK companies with less financial pressures, proxied by the Nickell and Nicolitsas (1999) borrowing ratio. Tobin's $Q$ is constructed as the market-to-book ratio of assets following Baker, Stein and Wurgler (2003) and Rauh (2006). The mean and the median $Q$ is 2.13 and 1.62 respectively, which is comparable with the US values in Rauh (2006).

The pension contribution data uses the company accounts reported in Datastream (item x114: pension contributions). Note that according to the MFR, pension contributions are smoothed over the years; so this measure may not represent the exact cash contributions of the firm. Bunn and Trivedi (2005) discussed this issue in detail and by comparing the smoothed figure with the non-smoothed hand-collected data on pension contributions from company accounts, they found that ,the Datastream measure of pension contributions successfully captures the time-series and cross-sectional variations within the 'true values'. They conclude that x114 is an eligible candidate for the company's pension contributions. The mean pension contribution is $1.7 \%$ of total assets and the median value is $1.3 \%$.

Figure 1 shows the distribution of pension contributions relative to assets for the sample years. The mean values are greater than the median values in all 4 years, indicating that the distribution of pension contributions is positively skewed. Moreover, it can be seen that the contribution level remains relatively stable during the course of the years, which is consistent with pension contributions being smoothed over time. The findings are confirmed by Figure 2, which plots the distribution of $P C / A$ over time. When pension contributions are divided according to percentiles, they also tent to follow a relatively stable and smoothed path, as shown in Figure 1.

Funding Status measures the difference between the market value of pension assets and the present value of pension liabilities, in which a positive value means the scheme is in deficit, i.e. underfunded (overfunded if the scheme has surplus). This measure is equivalent to the 
retirement benefit liabilities disclosed in the balance sheet according to the requirement by FRS17/IAS19 and this represents the true liabilities of the firm. Overfunding (Underfunding) is the absolute value of Funding Status for overfunded (underfunded) firms. The mean percentage of pension deficit to asset (Funding Status/A) is 9.5\% and of the total number of 675 observations, 601 are underfunded. The figures depicts the severe shortfall within UK pension schemes in recent years recognised after the introduction of FRS17, where all pension deficits have to be reported on the corporate balance sheet. The average overfunding and underfunding over assets is $12.3 \%$ and $12.5 \%$ with median value of $2.5 \%$ and $7.2 \%$, respectively. This is more clearly observed if one recodes the funding status into dummies ( 1 means underfunding and vice versa). The average value is 0.89 and the majority of the sample schemes are in deficit.

In order to check the relationship between pension funding status and pension contributions, a kernel regression is run on pooled contribution and funding status data, which enables one to investigate the nonparametric relation between the two variables. Figure 3 reports the result of kernel smoothing of pension contributions $(P C / A)$ on pension funding status (funding status/A) without imposing any functional formal using the Epanechnikov kernel. It can be seen that pension contributions increase as the funding status deteriorates. Moreover, there is a clear pattern that for schemes with less severe funding status, the change of pension contributions with respect to funding status is relatively small and stable, whilst for schemes with larger deficit, pension contributions increase dramatically as the funding status gets worse. This finding is consistent with the different smoothing times for schemes with different funding status, as imposed by the MFR, that the period over which a scheme can contribute to pay off pension deficit is much longer (10 years) for better funded schemes than for severely underfunded schemes (3 years).

\section{Empirical Results}

This section reports the regression results for the empirical models ver the period 2000-2005 using the two-step GMM-system estimator; first considering the effect of pension contributions on dividends and then on investment.

\section{i. Dividend Equations}

Table 2 shows the empirical results from estimating equation 6 for the dataset 2000-2005. For all estimates in Table 2, the GMM differenced equation uses all available instruments from $t=2$ 
to $t=6$. There are four firms that never pay any dividend throughout the duration of the sample and these are excluded from the analysis to ensure that these outliers do not drive the results; any clustering effect within the omitted firms are controlled by firm-specific fixed effects in the regressions. ${ }^{8}$

Specification (1) is the basic dividend specification without pension funding status included. The main findings are consistent with the empirical predictions of the theoretical models discussed previously. The coefficient on cash flow $(C F / A)$ has a point estimate of 2.547 . Although not within conventional level, it implies that higher cash flow will increase a firms dividend payments as predicted by the firm budget constrain equation 1. As a proxy for unobserved investment opportunities, Tobin's $Q$ has a point estimate of -0.042 and is significant at the usual levels. The result is consistent with both the pecking-order and the new view of tax theories, which states that firms prefer to use internally available funds to finance investment, and therefore a higher level of investment, as proxied by higher $Q$ level, would reduce dividend payments, which are also financed through internal funds such as retained earnings. Although not statistically significant, investment $(I / A)$ is negatively related to dividends, as predicted by firms' preference over internal funds. The coefficient estimates on leverage ratios (cgr and $b r$ ) are both statistically insignificant, which is consistent with the trade-off theory as firms with optimal debt levels do not necessarily have to undertake balance sheet adjustments through either dividends or investments.

The coefficient estimate of pension contributions in Specification (1) is -9.59 and is significant at $95 \%$ confidence level. The finding is consistent with the previously discussed theoretical models that pension contributions are regarded as negative cash flows and will either affect the firm's budget constraints in equation 1 according to the trade-off theory, or reduce the internal available funds to finance dividend payment according to the pecking order theory, both predicting that higher pension contributions will result in lower dividend payments. However the absolute magnitude of the coefficient estimate is large relative to the values in Rauh $(2006)^{9}$.

Specifications (2) and (3) add the pension funding status as a control to capture the correlation between funding status and unobserved investment opportunities. Specification (2) uses the

\footnotetext{
${ }^{8}$ Bunn and Trivedi (2005) report that firms that never pay dividend are mainly new and high-tech companies

${ }^{9}$ See Rauh (2006)) reports an estimate between -0.60 to -0.83 for pension contributions in his investment equation.
} 
overall funding status as the control and the point estimate of pension contribution reduces its magnitude to -3.82 but is not statistically significant. However when dividing funding status into overfunding and underfunding in Specification (3), pension contributions become significantly negatively related to dividends with a coefficient estimate of -11.85 . The funding status itself is positively related to dividend payments but the effect is not significant. Moreover, the coefficient estimate on overfunding is -2.14 and significant at $95 \%$ level. The negative relation is similar to the effect of Tobin's $Q$ on dividends, where a pension surplus implies better investment opportunities and higher investment demands, which will consequently reduce the funds for dividends.

One way to capture the interaction between pension contributions and the pension funding status is to isolate the proportion of the contribution that is made voluntarily by the sponsoring firm from the total contributions and only consider the mandatory contributions legally required by pension funding regulations (Rauh (2006)). We construct such a variable to approximate the mandatory contributions by defining a new pension contribution variable that equals a funding status dummy (fundingdummy in Table 2), which is 1 for underfunded schemes with $90 \%$ funding ratio under the FRS 17 valuation and 0 otherwise multiplied by the pension contribution $(P C / A) .{ }^{10}$ Specification (4) reports the dividend sensitivity of this simulated variable using underfunding and overfunding as control variables. Although the absolute magnitude of the coefficient estimate of pension contributions has increased to -15.49 , it has lost its explanatory power. This again confirms the relative imprecision of the 'simulated' mandatory contribution especially under the smoothed funding requirement by the MFR.

Specifications (5) and (6) remove the Nickell and Nicolitsas (1999) borrowing ratio from specifications (3) and (4) as it is highly correlated to the cash flow term $(C F / A)$ by construction. Removing this term does not alter the results significantly though pension contributions turn out to be negatively significant with a point estimate of -5.03 in Specification (5) using pension funding status as the control variable. Dropping the borrowing ratio also increases the statistical significance of investment, which becomes significant at $90 \%$ confidence level in Specification (5) and (6) with point estimates of -0.46 and -0.75 respectively.

\footnotetext{
${ }^{10}$ We have chosen $90 \%$ as the threshold funding ratio because this is the level under MFR which will trigger mandatory contributions. Furthermore, because of the MFR smoothing funding rules discussed in the previous
} 
The samples firms used in this study are all constituents of the FTSE350 index, and are relatively large in company size therefore in general we do not allow for any size effect in specifications (1) to (6). However we did try to divide the firms according to their size to pick up any group fixed effects in the regression, in specifications (7) and (8), where we include group dummies by dividing firms into quartiles according to their total assets. We found that group dummies are not significant, confirming our conjecture that group effects are not the driver of the results.

The autocorrelation test (row $\operatorname{AR}(1)$ and $\operatorname{AR}(2)$ in Table 2) enables one to check the dynamics of the dependent variable, and there is limited evidence of dividend persistence judged by the lagged dividend payments at first and second order. First-order serial correlation is only weakly significant in Specification (5), and the absence of second-order serial correlation ensures the validity of the GMM-system estimator. Furthermore, the Sargan test of overidentifying restriction cannot be rejected in all specifications.

\section{ii. Investment Equations}

Table 3 reports the coefficient estimates of the panel regression of investment on pension contributions in equation 8 using the two-step GMM-system estimator. The inclusion of lagged dependent variables ensures the two-step estimation method to be valid as there is no evidence of second-order serial correlation for all specifications. However contrary to the findings by Benito and Young (2007), there is no clear evidence of persistence in investment and moreover, the first lag of dependent variable is negatively significant in Specifications (1) to (3) and Specification (8) with point estimate between -0.46 and -0.40 . This might be caused by the positive correlation between investment and book assets as we have defined investments as total payments on fixed assets and if this is the case, a higher value of investment in the previous year will increase total assets, which consequently reduces the value of the dependent variable. For all specifications the Sargan test is not rejected, suggesting that the overidentifying restrictions are valid in our model.

Specification (1) is the principal equation to be tested. In the absence of pension funding status, the pension contributions are negatively related to investment with a point estimate of -7.79 but

sections, we regard it as inappropriate to construct the mandatory contribution variable in the context of the UK similar to the one used in Rauh (2006) as $\mathrm{MC}=\min (\mathrm{TC}$, pension deficit). 
are not significant at the $10 \%$ level. The estimate is close to that in dividend equation, providing support for the trade-off theory that balance sheet adjustments can take place through either channel. Specifications (2) and (3) add pension funding status into the basic specification and it is found to be negatively related to investment, consistent with our prediction that funding status is positively correlated to unobserved investment opportunities, though the coefficient estimates are again insignificant. Specification (4) uses the approximated mandatory pension contribution but the investment sensitivity remains insignificant. Our findings are weaker than those in Rauh (2006), who finds a strong negative relation between mandatory pension contribution and investment, but our results are similar to those in Bunn and Trivedi (2005), who also only find a weak negative relationship between pension contributions and investments. One possible explanation for these different investment sensitivities to pension contributions between the US and UK samples is that the definitions of mandatory contributions in the US may be a more precise measure of financial pressures imposed on corporate expenditures, and it seems harder to construct such a definitive measure in a UK context under the MFR regime.

Other than pension related variables, only total sales is weakly related to total investment in Specification (2), with a point estimate of 0.118. As a robustness check, we removed the borrowing ratio in Specification (5) and (6) and this reduces the standard errors in the cash flow terms, indicating that the borrowing ratio is indeed related to cash flow and picks up some of the effect of cash flow on corporate expenditure. Specifications (7) and (8) check whether there exists any size effects within our model by adding company specific fixed effects in the panel regression but the results are not significantly changed, implying that size effects are not the driver for our empirical findings. Another robustness test we undertook was to use the capital stock as the denominator in the investment equations as in Bunn and Trivedi (2005). These results are not reported but although we managed to find more significant estimates on other accounting variables, there is still no robust relation between pension contributions and investment. Moreover, this regression dramatically increases the magnitude and the standard errors of pension contribution variable to some abnormal level.

\section{Impact of post-2005 Funding Requirements on Corporate Expenditure Decisions}

In Section 3 we explained that post-2005, UK firms with DB pension schemes have had to make contributions under the new funding requirement set out in the Pensions Act 2004. Unlike the universal funding requirements for all firms under the MFR, the funding requirements that 
succeeded the MFR regulations, are more firm-specific and the contributions made by firms under such requirements represent a more precise measure of mandatory payments into the pension scheme, since under MFR any mandatory contributions could be spread over a number of years. In order to assess the impact of the new funding requirement on corporate expenditure decisions after the introduction of the Pensions Act 2004, additional tests were run by including group dummies using the most recent data until 2007.

The reason why this analysis is separated from the earlier empirical section of the paper is because the Datastream entry for pension contributions (x114) used in the previous section as well as some other variables (such as investment variables x1026 and x479) are no longer available after 2004. Post-2005 most financial data such as dividends and investments are replaced by data from Thomson ONE Banker and every effort has been made the ensure the consistency of the post-2004 data with the pre-2004 data. However pension contribution data is not available in Thomson ONE Banker, and in order to undertake the analysis, the first task is to approximate the pension contributions made by individual firms using the data that is available.

A DB pension scheme has two primary elements: scheme assets and scheme liabilities. Figure 4 shows the main components of the assets and liabilities of a typical DB scheme as disclosed in the footnote of the firm's financial statement according to FRS 17. The left-hand side of Figure 4 shows the composition of pension assets. In the UK, both the sponsoring firms and member employees have to make contributions to the DB scheme trust, which is usually invested into bonds, equities and other asset classes in order to meet its long-term obligations. Therefore the fair value of the pension assets at the end of the year equals the sum of assets value at the beginning of the year plus the investment returns on the assets and any new contributions made to the scheme minus pension benefits paid during the year. The right-hand side of Figure 4 shows the calculation of pension obligations. There are two main kinds of costs accrued during the accounting period: service cost and interest cost. Service cost is the additional liability created because another year has elapsed, for which all current employees get another year's pension benefit for their service. Pension interest cost is the annual accrued interest on previously incurred pension benefit obligations reflecting the increase of the present value of the projected pension obligation as employees are getting one year closer to receiving their pension benefits. The year-end pension liabilities are equal to the sum of opening liabilities and pension costs accrued during the year minus the obligations that are paid off (benefits paid) during the year. From Figure 4, the fair value of a DB scheme in year $t$ can be written as: 


$$
P A_{t}=P A_{t-1}+R O A_{t}+P C_{t}-P B_{t}
$$

Rearranging equation 9 we have:

$$
P C_{t}=P A_{t}-P A_{t-1}-R O A_{t}+P B_{t}
$$

which shows how pension contributions are approximated when such data is unavailable from Datastream. In accordance with the disclosure requirement of the pension accounting standards (FRS17 and IAS19), the fair value of scheme assets and the return on scheme assets in 2005 and onwards are available from Thompson One Banker ${ }^{11}$. Although the annual benefits paid are not available from the Thompson dataset, this only represents a small proportion of the total pension assets, so we simulate the pension contributions using the following equation:

$$
P C_{t}=P A_{t}-P A_{t-1}-R O A_{t t}
$$

In order to check whether the sensitivities of dividends/investment to pension contributions $\left(\alpha_{8}\right.$ and $\beta_{8}$ in equation 6 and 8 respectively), have changed after the new regulations were introduced, a time dummy $\left(T_{2005}\right)$ is interacted with the $P C_{i t-1}$ variable in both dividend and investment equations, to measure the effects on the slope coefficients. So for the dividend equation, the modified specification is

$$
\begin{aligned}
\frac{D_{i t}}{A_{i t}}= & \sum_{j=1}^{2} \alpha_{j} \frac{D_{i t-j}}{A_{i t-j}}+\alpha_{3} \frac{I_{i t-1}}{A_{i t-1}}+\alpha_{4} \frac{C F_{i t-1}}{A_{i t-1}}+\alpha_{5} c g r_{i t-1}+\alpha_{6} b r_{i t-1}+\alpha_{7} Q_{i t-1} \\
& +\alpha_{8} \frac{P C_{i t-1}}{A_{i t-1}}+\alpha_{9}\left(T_{2005} \times \frac{P C_{i t-1}}{A_{i t-1}}\right)+\mu X_{i t-1}+\sum_{t=2002}^{2006} \gamma_{t}^{D} \tau_{t}+\zeta_{i}^{D}+\varepsilon_{i t}^{D}
\end{aligned}
$$

and for the investment equation

$$
\begin{aligned}
\frac{I_{i t}}{A_{i t}}= & \sum_{j=1}^{2} \beta_{j} \frac{I_{i t-j}}{A_{i t-j}}+\beta_{3} \frac{S_{i t-1}}{A_{i t-1}}+\beta_{4} \frac{C F_{i t-1}}{A_{i t-1}}+\beta_{5} c g r_{i t-1}+\beta_{6} b r_{i t}+\beta_{7} Q_{i t-1} \\
& +\beta_{8} \frac{P C_{i t-1}}{A_{i t-1}}+\beta_{9}\left(T_{2005} \times \frac{P C_{i t-1}}{A_{i t-1}}\right)+v X_{i t-1}+\sum_{t=2002}^{2006} \gamma_{t}^{I} \tau_{t}+\zeta_{i}^{I}+\varepsilon_{i t}^{I}
\end{aligned}
$$

where $T_{2005}$ is a dummy variable equal to 0 for observations before 2005 and 1 in and after 2005, when the new funding requirements of the Pensions Act 2004 came into effect. Whilst the parameters $\alpha_{9}$ and $\beta_{9}$ capture the change in slope coefficients, changes in the intercept terms before and after the introduction of new funding requirements are captured by the individual year dummies ( $\gamma_{t}^{D}$ and $\gamma_{t}^{I}$ in the Eq (11) and (12) respectively) or by the single dummy variable 
$T_{2005}$. If the new funding requirement and the required pension contribution made under the Pensions Act 2004 do prove to be more financially binding and impose greater financial pressures on firms, then the dividend sensitivity should increase and the post-2005 dummies should be significant in explaining the regression results.

Descriptive statistics for the full sample of 935 observations over 196 firms for the period 20002007 are given in Panel B of Table 1. One noticeable difference with the earlier period is that the mean size of the simulated pensions contributions are higher at 2.2 per cent of assets. Table 4 and Table 5 show the regression results for dividend and investment equations respectively estimated of the full sample period. The first three columns in Table 4 report the empirical results using only individual year dummies for the three core specifications. Specification (1) reports the results without any funding status control, specification (2) is with funding status included, and specification (3) with over- and underfunding as control variables. The last three columns consider the change of slope coefficient for pension contribution variables as well as a specific time dummy $\left(T_{2005}\right)$ that measures the change of circumstances before and after Pensions Act 2004 in the different specifications.

The number of observations in Table 4 increases to 891 from the 511 in Table 2, but the additional data does not alter the main results: pension contributions are still negatively related to dividend payments even after controlling for the pension funding status, although the absolute value of the coefficient over the whole sample period is reduced to -1.524 , though this is probably explained by the mean value of the pension contributions to assets (including the simulated values) in Panel B of Table 1 being $2.2 \%$, which is significantly larger than the previously used PC/A variable. Also in specification (4) when we replace the mandatory contribution with the simulated mandatory contribution calculated as described in the previous section, the coefficient is still significantly and negatively related to dividend payments. The results are similar when using funding status as control variables. Specification (6) adds the interaction term between time and MC (Fundingdummy $\left.{ }_{i t-1} \times T_{2005} \times(P C / A)_{i t-1}\right)$ to pick up the pre- and post-Pensions Act 2004 effects whilst Specification (7) further adds a 2005 time dummy. The estimate of $\alpha_{9}$, which identifies the effect of the Pensions Act 2004 changes is significantly negative in both Specfications (6) and (7), indicating a more pronounced dividend

\footnotetext{
${ }^{11}$ Data on retirement benefits are available in Thompson One Banker from 2001, when FRS17 was introduced. However it was not until 2005, when the standard was fully implemented and mandatory disclosure was required, that such data became available for most of the companies with DB schemes.
} 
sensitivity to pension contributions under the new funding requirements. We also constructed additional time dummy variables allowing for changes in slope coefficients for variables other than pension contributions, such as pension funding status. However we found no significant effects of these control variables on dividend payments after the introduction of the new funding requirement.

Turning to the investment equation in Table 5, we follow Benito and Young (2007) and Blundell and Bond (1998) and include both lagged $(t-1)$ and contemporary $(t)$ independent variables ${ }^{12}$. Pension contributions still have no significant impact on investment when adding the additional data into the regressions in Specifications (1) and (2). However when we add both over- and underfunding as control variables in Specification (3), the coefficient estimate for pension contributions is -0.315 and significant at $95 \%$ confidence level. When using the simulated mandatory contributions variable (Fundingdummy $\left.y_{i t-1} \times(P C / A)_{i t-1}\right)$ in the regression, Specification (5) shows that the absolute investment sensitivities are larger when looking at mandatory contributions than total contributions. Specifications (6) and (7) include the interaction term for time and MC (Fundingdummy $\left.{ }_{i t-1} \times T_{2005} \times(P C / A)_{i t-1}\right)$, and the 2005 time dummy $\left(T_{2005}\right)$. Similar to the findings from the dividend equation in Table 4 , the investment sensitivity of mandatory contributions after the introduction of the new funding rules are significantly 'more negative' than before the introduction of the new funding rules. This indicates that the firm-specific funding requirements established under the Pensions Act 2004 have had a more direct impact on firms' capital expenditure decisions with respect to both dividends and investments.

As we have already noted, the coefficients on the simulated pension contributions in Tables 4 and 5 for the extended dataset, differ from the values in Tables 2 ands 3. Bunn and Trivedi (2005) discuss at length their choice of pension contribution data (DataStream item x114) and whether it represent a sensible measure of the pension contributions under the accounting standard SSAP 24.. In order to check whether our simulated pension contribution data is an appropriate measure of true pension contributions, the calculation in equation 11 is undertaken for observations before 2005 and the results are compared with the values for the actual pension contribution taken from Datastream item x114. The correlation coefficient between the simulated data and the DataStream disclosures is 0.812 , indicating that our simulated pension contributions does

${ }^{12}$ We do not report the contemporary variables to save space in the table. 
capture most of the information in the actual pension contributions. In addition as a robustness check on our results in Tables 2 and 3, regressions were run using the simulated pension contribution for all sample years ${ }^{13}$. In the unreported results, the coefficient on the simulated pension contributions in the dividend equation was -0.62 , and in the investment equation was 0.72. Only the coefficient of the investment equation is significant, suggesting that the firmspecific contributions required by the Pensions Act 2004 may have larger effects on investment than dividend decisions. The coefficient estimates for the dummies (Fundingdummy and $T_{2005}$ ) are still significant, indicating that although the simulated pension contributions are a noisier measure that the contribution data used in Bunn and Trivedi (2005) before 2005, the post-2005 pension contributions do have significant impact on firms' expenditure decisions.

\section{Conclusions}

It has been shown that in an imperfect market where taxes and costly external finance exist, the balance sheet adjustments by financially constrained firms deviates from those implied by the Modigliani-Miller theorem. This paper investigates a particular form of financial pressurecompany pension contributions, and its relation between corporate expenditures on dividends and investments whilst controlling for the correlations between the funding status of pension schemes and the firm's unobserved investment opportunities.

Using a panel of all UK FTSE350 companies with defined benefit schemes between 2001 and 2004, we established a strong negative relation between the firm's dividend payments and its pension contributions even controlling for the endogeneity of pension funding status on investments. However, we find that the effect of pension contribution on investment is weaker than that found in Rauh (2006), implying that any balance sheet adjustments are more likely to take place through financial channels such as dividends rather than real channels such as investment.

In the UK under the MFR, pension contributions for underfunded firms are smoothed over a number of years and has been proved to be a poor reflection of firms' financial conditions and

\footnotetext{
${ }^{13}$ Of course a more sensible check would be to use samples before2005, however this is not possible because of the relative scarce of the pension scheme data (on DataStream), which is essential in calculating the simulated contributions.
} 
insufficient to provide the promised benefits by the scheme. However has subsequently been replace from 2005 with a more firm-specific funding requirement, where firms can focus on developing an appropriate funding strategy for meeting their own specific pension commitments and make the relevant investment decisions accordingly. The pension contributions post-2005 are likely to be is a better measure of each firm's specific financial pressures, and may be expected to have a more direct influence on the firm's corporate expenditure decisions.

We examined whether the new funding requirement under the Pensions Act 2004 have had any effect on firms' pension contributions and accordingly their corporate expenditure decisions, by extending the sample to include data after the introduction of the new funding requirement. For both dividend and investment equations, we found that the dividend and investment sensitivities to pension contributions are more pronounced in and after 2005, indicating the contributions made under the new funding requirement provides a more precise measure of the financial pressure of the pension scheme than the smoothed contributions under the minimum funding requirement. 


\section{References}

Arellano, M. and S. Bond, 1991, Some tests of specification for panel data: Monte Carlo evidence and an application to employment equations, Review of Economic Studies 58, 277-97.

Arellano, M., and O. Bover. 1995, Another look at the instrumental variables estimation of error-components models, Journal of Econometrics 68, 29-51.

Asquith, P. and D. W. Mullins, Jr, 1986, Equity issues and offering dilution, Journal of Financial Economics 15, 61-89.

Auerbach, A., 1979, Wealth maximization and the cost of capital, Quarterly Journal of Economics 94, 433-36.

Auerbach, A. and K. Hassett, 2002, On the marginal source of investment funds, Journal of Public Economics 87, $205-32$.

Baker, M., J. C. Stein, and J. Wurgler, 2003, When does the market matter? Stock prices and the investment of equity-dependent firms, Quarterly Journal of Economics 118, 909-968.

Benito, A. and G. Young, 2007, Financial pressure and balance sheet adjustment by UK firms, Oxford Bulletin of Economics and Statistics, 581-602.

Blundell, R. W. and S. Bond, 1998, Initial conditions and moment restrictions in dynamic panel data models, Journal of Econometrics 87, 115-43.

Blundell, R. W., S. Bond, M. P. Devereux and F. Schiantarelli, 1992, Investment and Tobin's Q: Evidence from company panel data, Journal of Econometrics 51, 233-57.

Bond, S, L. Chennells and M. P. Devereux, 1996, Taxes and company dividends: a microeconometric investigation exploiting cross-section variation in taxes, Economic Journal 106, 320-33.

Bunn, P. and K. Trivedi, 2005, Corporate expenditures and pension contributions: evidence from UK company accounts, Bank of England Working Paper no. 276.

Chung, K.H. and S.W. Pruitt, 1994, A simple approximation of Tobin's Q, Financial Management 23, 70-74.

Davis, E. P. (2000), Regulation of private pensions - a case study of UK, Discussion Paper, PI-0009, The Pensions Institute.

Dierkens, N., 1991, Information asymmetry and equity issues, Journal of Financial and Quantitative Analysis 26, 181-99.

Eckbo, E., 1986, The valuation effects of corporate debt offerings, Journal of Financial Economics 15, 119-52.

Fama, E. F. and K. R. French, 2002, Testing trade-off and pecking order predictions about dividends and debt, The Review of Financial Studies 15, 1-33.

Fazzari, S. M., G. R. Hubbard and B. C. Petersen, 1988, Financing constraints and corporate investment, Brookings Papers on Economic Activity 1, 141-195.

Frank, M. Z. and V. K. Goyal, 2003, Testing the pecking order theory of capital structure, Journal of Financial Economics 67, 217-248.

Franzoni, F. and J. M. Marin, 2006, Pension plan funding and stock market efficiency, Journal of Finance 61, 921956.

Gomes, J. F., 2001, Financing investment, American Economic Review 91, 1263-1285.

Graham, J. R., 1996, Debt and the marginal tax rate, Journal or Financial Economics 41, 41-73.

Graham, J. R., 2000, How big are the tax benefits of debt? Journal of Finance 55, 1901-1940.

Gross, D. B., 1995, The investment and financing decisions of liquidity constrained firms, Unpublished Ph.D. dissertation, Massachusetts Institute of Technology. 
Kaplan, S. N., and L. Zingales, 1997, Do investment-cash flow sensitivities provide useful measures of financing constraints? Quarterly Journal of Economics 112, 169-215.

Kaplan, S. N., and L. Zingales, 2000, Investment-cash flow sensitivities are not valid measures of financing constraints, Quarterly Journal of Economics 115, 707-712.

King, M., 1977, Public policy and the corporation, Cambridge University Press.

Langbein, J. H., and B. A. Wolk, 2000, Pension and Employee Benefit Law, 3rd ed. Foundation Press, New York.

Lintner, J. 1956, Distribution of incomes of corporations among dividends, retained earnings and taxes, American Economic Review 46, 97-113.

Mackie-Mason, J. K., 1990, Do taxes affect corporate financing decisions?, Journal of Finance 45, 1471-1493.

Modigliani, F. and M. Miller, 1958, The cost of capital, corporation finance, and the theory of investment, American Economic Review 48, 261-97.

Myers, S. C., 1984, The capital structure puzzle, Journal of Finance 39, 575-92.

Myers, S. C., 2001, Capital structure, Journal of Economic Perspectives 15, 81-102.

Myers, S. C. and N. S. Majluf, 1984, Corporate financing and investment decisions when firms have information that investors do not have, Journal ofFinancial Economics 13, 187-221.

Nickell, S. and D. Nicolitsas, 1999, How does financial pressure affect firms? European Economic Review 43, 43556.

Rauh, J. D., 2006, Investment and financing constraints: Evidence from the funding of corporate pension plans, Journal of Finance 61, 33-71.

Rajan, R.G., and L. Zingales, 1995, What do we know about capital structure? Some evidence from international data. Journal of Finance, 50, 1421-1460

Shyam-Sunder, L., 1991, The stock price effect of risky versus safe debt, Journal of Financial and Quantitative Analysis 26, 549-58.

Shyam-Sunder, L. and S. C. Myers, 1999, Testing static trade-off against pecking order models of capital structure, Journal of Financial Economics 51, 219-44.

Tobin J., 1969, A general equilibrium approach to monetary theory, Journal of Money Credit and Banking 1, 15-29

Wald, J. K. 1999, How firm characteristics affect capital structure: An international comparison. Journal ofFinancial Research 22, 161-87. 
Table 1

\section{Descriptive Statistics}

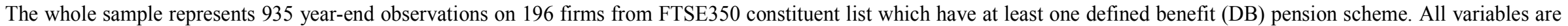

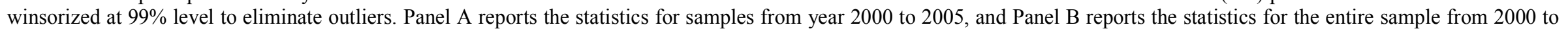

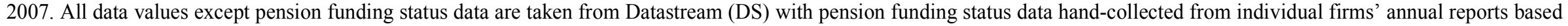

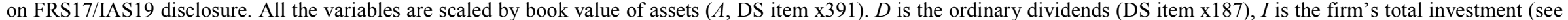

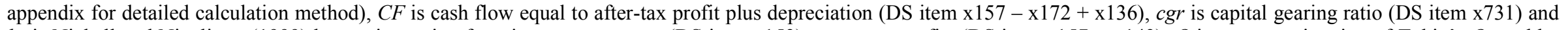

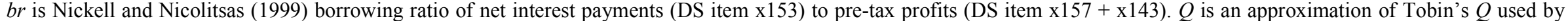

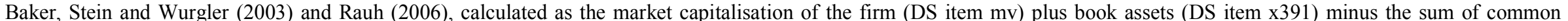

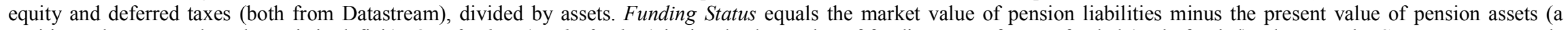

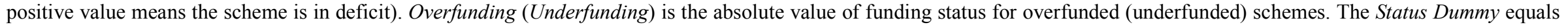
1 (0) for underfunded (overfunded) schemes.

\begin{tabular}{|c|c|c|c|c|c|c|c|c|}
\hline & \multicolumn{4}{|c|}{ Panel A } & \multicolumn{4}{|c|}{ Panel B } \\
\hline & \multicolumn{4}{|c|}{ Data from 2000 to 2005 , firms $=180$, observations $=675$} & \multicolumn{4}{|c|}{ Data from 2000 to 2007 , firms $=196$, observations $=935$} \\
\hline & & & Standard & & & & Standard & \\
\hline & Mean & Median & Deviation & No. Observations & Mean & Median & Deviation & No. Observations \\
\hline$D / A$ & 0.056 & 0.040 & 0.187 & 675 & 0.024 & 0.042 & 0.712 & 935 \\
\hline$I / A$ & 0.064 & 0.058 & 0.209 & 675 & 0.016 & 0.051 & 1.526 & 935 \\
\hline$C F / A$ & 0.144 & 0.142 & 0.451 & 675 & -0.002 & 0.151 & 3.554 & 935 \\
\hline $\operatorname{cgr} r$ & 0.651 & 0.508 & 2.797 & 675 & 0.604 & 0.478 & 2.394 & 935 \\
\hline$b r$ & 0.148 & 0.179 & 1.610 & 675 & 0.808 & 0.217 & 4.094 & 935 \\
\hline$Q$ & 2.129 & 1.624 & 1.798 & 675 & 1.649 & 1.526 & 9.932 & 935 \\
\hline$P C / A$ & 0.017 & 0.013 & 0.025 & 675 & 0.022 & 0.011 & 0.081 & 935 \\
\hline FundingDummy & 0.890 & 1 & 0.313 & 675 & 0.906 & 1 & 0.292 & 935 \\
\hline$P C / A \times$ FundingDummy & 0.016 & 0.011 & 0.025 & 675 & 0.021 & 0.009 & 0.078 & 935 \\
\hline Funding Status/A & 0.098 & 0.059 & 0.218 & 675 & 0.086 & 0.048 & 0.278 & 935 \\
\hline Overfunding/A & 0.123 & 0.025 & 0.327 & 74 & 0.107 & 0.021 & 0.302 & 88 \\
\hline Underfunding $/ A$ & 0.125 & 0.072 & 0.183 & 601 & 0.106 & 0.058 & 0.268 & 847 \\
\hline
\end{tabular}




\section{Table 2}

\section{GMM-system Regression of Dividends on Pension Contributions}

The table presents the results for the two-step GMM-system estimation in a fixed effect panel data model using PcGive. Variables are scaled by end-of-year total book value of assets $(A)$ where applicable. $D$ is the firm's dividend payment, $I$ is investment expenditure, $C F$ is cash flow, $c g r$ is capital gearing ratio, $b r$ is the borrowing ratio as in Nickell and Nicolitsas (1999), $Q$ is Tobin's $Q$ and $P C$ is the firm's pension contributions. Specifications (1) and (4) consider only the effect of pension contributions. In Specification (2) and (5) the pension funding status is used as a control for its correlation with unobserved investment opportunities. Specifications (3) and (6) the funding status control is underfunding and overfunding, separately. In Specifications (3) to (6) the borrowing ratio is excluded from the regressions. Specifications (7) and (8) add company specific group effects into Specification (1) and (2). Sargan is a $\chi^{2}$ test of overidentifying restrictions. Asymptotic robust stand errors are reported in parenthesis. $*, * *, * * *$ stand for $10 \%, 5 \%$ and $1 \%$ significance levels, respectively.

\begin{tabular}{|c|c|c|c|c|c|c|c|c|}
\hline \multirow[b]{2}{*}{ Specifications } & \multicolumn{8}{|c|}{ 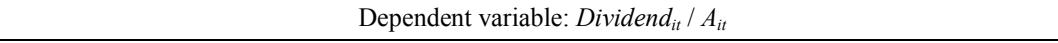 } \\
\hline & (1) & (2) & (3) & (4) & (5) & (6) & (7) & (8) \\
\hline \multirow[t]{2}{*}{$(D / A)_{i t-1}$} & -0.821 & 0.767 & -1.368 & -3.311 & 0.280 & -0.616 & 0.465 & 0.538 \\
\hline & $(1.699)$ & $(1.716)$ & $(1.605)$ & $(4.185)$ & $(1.106)$ & $(1.08)$ & $(1.513)$ & $(0.808)$ \\
\hline \multirow[t]{2}{*}{$(D / A)_{i t-2}$} & 0.025 & 0.010 & 0.030 & 0.025 & 0.009 & $0.024 *$ & 0.029 & 0.009 \\
\hline & $(0.019)$ & $(0.007)$ & $(0.022)$ & $(0.037)$ & $(0.006)$ & $(0.015)$ & $(0.021)$ & $(0.013)$ \\
\hline \multirow[t]{2}{*}{$(I / A)_{i t-1}$} & -0.425 & -0.263 & -0.635 & -1.385 & $-0.461 *$ & $-0.745^{*}$ & -0.653 & -0.101 \\
\hline & $(0.450)$ & $(0.488)$ & $(0.491)$ & $(1.417)$ & $(0.263)$ & $(0.419)$ & $(0.638)$ & $(0.279)$ \\
\hline \multirow[t]{2}{*}{$(C F / A)_{i t-1}$} & $2.547 *$ & -0.218 & $3.196 * *$ & 4.890 & 0.356 & $2.356^{* *}$ & $1.772 *$ & -0.151 \\
\hline & $(1.534)$ & $(1.468)$ & $(1.586)$ & $(5.368)$ & $(0.825)$ & $(1.018)$ & $(1.030)$ & $(0.569)$ \\
\hline \multirow[t]{2}{*}{$c g r_{i t-1}$} & 0.009 & 0.000 & 0.010 & 0.016 & 0.001 & 0.005 & 0.005 & 0.001 \\
\hline & $(0.007)$ & $(0.004)$ & $(0.009)$ & $(0.021)$ & $(0.002)$ & $(0.005)$ & $(0.006)$ & $(0.002)$ \\
\hline \multirow[t]{2}{*}{$b r_{i t-1}$} & -0.071 & 0.046 & -0.087 & -0.083 & & & 0.017 & 0.072 \\
\hline & $(0.152)$ & $(0.110)$ & $(0.145)$ & $(0.252)$ & & & $(0.073)$ & $(0.046)$ \\
\hline \multirow[t]{2}{*}{$Q_{i t-1}$} & $-0.042 *$ & 0.004 & -0.051 & -0.097 & 0.000 & -0.039 & -0.048 & 0.000 \\
\hline & $(0.022)$ & $(0.010)$ & $(0.034)$ & $(0.123)$ & $(0.011)$ & $(0.025)$ & $(0.035)$ & $(0.006)$ \\
\hline \multirow[t]{2}{*}{$(P C / A)_{i t-1}$} & $-9.591 * *$ & -3.823 & $-11.848^{* *}$ & & $-5.033^{*}$ & $-8.459^{* *}$ & $-7.521 *$ & -2.553 \\
\hline & $(4.825)$ & $(3.921)$ & $(5.946)$ & & $(3.233)$ & $(3.859)$ & $(3.926)$ & $(3.930)$ \\
\hline \multirow[t]{2}{*}{$(\text { Funding status } / A)_{i t-1}$} & & 0.315 & & & 0.537 & & & 0.108 \\
\hline & & $(0.576)$ & & & $(0.363)$ & & & $(0.240)$ \\
\hline \multirow{2}{*}{$\begin{array}{l}\text { Fundingdummy } \\
(P C / A)_{i t-1} \times\end{array}$} & & & & -15.490 & & & & \\
\hline & & & & (17.630) & & & & \\
\hline \multirow[t]{2}{*}{$(\text { Overfunding } / A)_{i t-1}$} & & & $-2.136 * *$ & 2.529 & & $-1.652 * *$ & $-1.638^{*}$ & \\
\hline & & & $(0.965)$ & $(2.907)$ & & $(0.733)$ & $(0.844)$ & \\
\hline \multirow[t]{2}{*}{ (Underfunding $/ A)_{i t-1}$} & & & 0.102 & 0.366 & & 0.237 & -0.023 & \\
\hline & & & $(0.638)$ & $(0.953)$ & & $(0.504)$ & $(0.480)$ & \\
\hline Size effects & No & No & No & No & No & No & Yes & Yes \\
\hline Year effects & yes & yes & yes & Yes & yes & yes & Yes & Yes \\
\hline $\operatorname{AR}(1)(p$-value $)$ & 0.515 & 0.513 & 0.396 & 0.592 & 0.069 & 0.124 & 0.323 & 0.367 \\
\hline $\operatorname{AR}(2)(p$-value $)$ & 0.708 & 0.264 & 0.286 & 0.882 & 0.224 & 0.399 & 0.915 & 0.719 \\
\hline Sargan (p-value) & 0.971 & 0.783 & 0.957 & 0.903 & 0.594 & 0.841 & 0.852 & 0.668 \\
\hline Number of firms & 164 & 164 & 164 & 164 & 164 & 164 & 164 & 164 \\
\hline No. of observations & 511 & 511 & 511 & 511 & 511 & 511 & 510 & 510 \\
\hline
\end{tabular}




\section{Table 3}

\section{GMM-system Regression of Investments on Pension Contributions}

The table presents the results for the two-step GMM-system estimation in a fixed effect panel data model using PcGive. Variables are scaled by end-of-year total book value of assets $(A)$ where applicable. $I$ is the firm's investment expenditure, $C F$ is cash flow, $c g r$ is capital gearing ratio, $b r$ is the borrowing ratio as in Nickell and Nicolitsas (1999), $Q$ is Tobin's $Q, S$ is total sales and $P C$ is the firm's pension contributions. Specifications (1) and (4) consider only the effect of pension contributions. In Specification (2) and (5) the pension funding status is used as a control for its correlation with unobserved investment opportunities. Specifications (3) and (6) the funding status control is underfunding and overfunding, separately. In Specifications (3) to (6) the borrowing ratio is excluded from the regressions. Specifications (7) and (8) add company specific group effects into Specification (1) and (2). Sargan is a $\chi^{2}$ test of overidentifying restrictions. Asymptotic robust stand errors are reported in parenthesis. $*, * *, * * *$ stand for $10 \%, 5 \%$ and $1 \%$ significance levels, respectively.

\begin{tabular}{|c|c|c|c|c|c|c|c|c|}
\hline \multirow[b]{2}{*}{ Specifications } & \multicolumn{8}{|c|}{ Dependent variable: Investment ${ }_{i t} / A_{i t}$} \\
\hline & (1) & (2) & (3) & (4) & (5) & (6) & (7) & (8) \\
\hline \multirow[t]{2}{*}{$(I / A)_{i t-1}$} & $-0.400 *$ & $-0.462 * *$ & $-0.463 * *$ & $-0.543 * *$ & -0.314 & -0.343 & -0.389 & $-0.433 *$ \\
\hline & $(0.240)$ & $(0.219)$ & $(0.215)$ & $(0.271)$ & $(0.263)$ & $(0.224)$ & $(0.243)$ & $(0.251)$ \\
\hline \multirow[t]{2}{*}{$(I / A)_{i t-2}$} & -0.155 & -0.136 & -0.126 & -0.108 & -0.093 & -0.104 & -0.150 & -0.132 \\
\hline & $(0.151)$ & $(0.117)$ & $(0.128)$ & $(0.103)$ & $(0.144)$ & $(0.134)$ & $(0.136)$ & $(0.115)$ \\
\hline \multirow[t]{2}{*}{$(C F / A)_{i t-1}$} & -0.326 & 0.267 & 0.303 & 0.548 & 0.373 & 0.255 & 0.237 & 0.246 \\
\hline & $(1.127)$ & $(1.019)$ & $(1.039)$ & $(0.957)$ & $(0.819)$ & $(0.838)$ & $(0.816)$ & $(0.885)$ \\
\hline \multirow[t]{2}{*}{$c g r_{i t-1}$} & 0.001 & 0.008 & 0.008 & 0.014 & 0.000 & -0.001 & 0.003 & 0.006 \\
\hline & $(0.015)$ & $(0.018)$ & $(0.019)$ & $(0.024)$ & $(0.014)$ & $(0.015)$ & $(0.019)$ & $(0.024)$ \\
\hline \multirow[t]{2}{*}{$b r_{i t-1}$} & -0.440 & -0.418 & -0.378 & -0.538 & & & -0.209 & -0.291 \\
\hline & $(0.631)$ & $(0.611)$ & $(0.603)$ & $(0.791)$ & & & $(0.619)$ & $(0.646)$ \\
\hline \multirow[t]{2}{*}{$Q_{i t-1}$} & -0.018 & -0.052 & -0.054 & -0.082 & -0.030 & -0.031 & -0.034 & -0.042 \\
\hline & $(0.042)$ & $(0.052)$ & $(0.055)$ & $(0.077)$ & $(0.055)$ & $(0.057)$ & $(0.049)$ & $(0.067)$ \\
\hline \multirow[t]{2}{*}{$(S / A)_{i t-1}$} & 0.129 & $0.118^{*}$ & 0.110 & 0.111 & 0.089 & 0.096 & $0.117 *$ & 0.120 \\
\hline & $(0.097)$ & $(0.070)$ & $(0.075)$ & $(0.079)$ & $(0.069)$ & $(0.071)$ & $(0.074)$ & $(0.086)$ \\
\hline \multirow[t]{2}{*}{$(P C / A)_{i t-1}$} & -7.789 & -3.714 & -2.916 & & -1.766 & -2.424 & -4.542 & -4.803 \\
\hline & $(6.357)$ & $(7.431)$ & $(6.788)$ & & $(5.767)$ & $(5.863)$ & $(5.680)$ & $(6.425)$ \\
\hline \multirow[t]{2}{*}{$(\text { Funding status } / A)_{i t-1}$} & & -0.859 & & & -0.769 & & -0.609 & \\
\hline & & $(1.264)$ & & & (1.019) & & $(1.295)$ & \\
\hline \multirow{2}{*}{$\begin{array}{l}\text { Fundingdummy } y_{i t-1} \times \\
(P C / A)_{i t-1}\end{array}$} & & & & -4.472 & & & & \\
\hline & & & & $(8.377)$ & & & & \\
\hline \multirow[t]{2}{*}{$(\text { Overfunding } / A)_{i t-1}$} & & & 1.131 & 1.075 & & -2.075 & & 3.516 \\
\hline & & & $(5.248)$ & $(4.875)$ & & $(5.730)$ & & $(9.795)$ \\
\hline \multirow[t]{2}{*}{$(\text { Underfunding } / A)_{i t-1}$} & & & -0.786 & -0.835 & & -0.761 & & -0.349 \\
\hline & & & $(1.234)$ & $(1.163)$ & & $(1.052)$ & & (1.219) \\
\hline Size effects & No & No & No & No & No & No & Yes & Yes \\
\hline Year effects & Yes & Yes & Yes & Yes & Yes & Yes & Yes & Yes \\
\hline $\operatorname{AR}(1)(p$-value $)$ & 0.972 & 0.939 & 0.772 & 0.912 & 0.355 & 0.878 & 0.756 & 0.527 \\
\hline $\operatorname{AR}(2)(p$-value $)$ & 0.987 & 0.402 & 0.461 & 0.570 & 0.477 & 0.286 & 0.839 & 0.754 \\
\hline Sargan (p-value) & 0.892 & 0.905 & 0.774 & 0.842 & 0.827 & 0.764 & 0.795 & 0.679 \\
\hline Number of firms & 163 & 163 & 163 & 163 & 163 & 163 & 163 & 163 \\
\hline No. of observations & 496 & 496 & 496 & 496 & 496 & 496 & 495 & 495 \\
\hline
\end{tabular}


Table 4

\section{Impact of New post-2005 Funding Requirements: Dividend Equation}

The table presents the results for the two-step GMM-system estimation in a fixed effect panel data model using PcGive. Variables are scaled by end-of-year total book value of assets $(A)$ where applicable. $D$ is the firm's dividend payment, $I$ is investment expenditure, $C F$ is cash flow, $c g r$ is capital gearing ratio, $b r$ is the borrowing ratio as in Nickell and Nicolitsas (1999), $Q$ is Tobin's $Q$ and $P C$ is the firm's pension contributions. $T_{2005}$ is a time dummy set to be 0 for observations before 2005 and 1 in and after 2005. Specifications (1) considers only the effect of pension contributions. In Specification (2) the pension funding status is used as a control for its correlation with unobserved investment opportunities. Specifications (3) the funding status control is underfunding and overfunding, separately. Specifications (4) to (6) use proximate mandatory contributions in the regression. The sample data range from fiscal year 2000 to 2007 and p-values for the time dummies of year 2004 to 2007 are reported. Asymptotic robust stand errors are reported in parenthesis. *,**,*** stand for $10 \%$, $5 \%$ and $1 \%$ significance levels, respectively.

\begin{tabular}{|c|c|c|c|c|c|c|c|}
\hline \multirow[b]{2}{*}{ Specifications } & \multicolumn{7}{|c|}{ Dependent variable: Dividend $_{i t} / A_{i t}$} \\
\hline & (1) & (2) & (3) & (4) & (5) & (6) & (7) \\
\hline \multirow[t]{2}{*}{$\overline{(D / A)_{i t-1}}$} & 0.194 & 0.402 & 0.496 & -0.793 & 0.568 & -0.864 & -0.469 \\
\hline & $(0.908)$ & $(0.677)$ & $(0.420)$ & $(0.806)$ & $(1.812)$ & $(0.758)$ & $(0.765)$ \\
\hline \multirow[t]{2}{*}{$(D / A)_{i t-2}$} & -0.008 & -0.015 & -0.028 & 0.002 & 0.037 & -0.009 & -0.007 \\
\hline & $(0.021)$ & $(0.024)$ & $(0.028)$ & $(0.023)$ & $(0.029)$ & $(0.021)$ & $(0.026)$ \\
\hline \multirow[t]{2}{*}{$(I / A)_{i t-1}$} & $1.009 * * *$ & $0.840 * * *$ & 0.478 & $1.304 * * *$ & 0.698 & $0.848^{* * *}$ & $0.959 * * *$ \\
\hline & $(0.130)$ & $(0.120)$ & $(0.722)$ & $(0.062)$ & $(0.844)$ & $(0.160)$ & $(0.170)$ \\
\hline \multirow[t]{2}{*}{$(C F / A)_{i t-1}$} & 0.100 & 0.052 & 0.047 & 0.216 & 0.169 & $0.217^{*}$ & 0.150 \\
\hline & $(0.153)$ & $(0.100)$ & $(0.058)$ & $(0.144)$ & $(0.318)$ & $(0.130)$ & $(0.92)$ \\
\hline \multirow[t]{2}{*}{$c g r_{i t-1}$} & $-0.201 * * *$ & $-0.165 * * *$ & $-0.257 * * *$ & -0.003 & -0.006 & 0.001 & 0.000 \\
\hline & $(0.051)$ & $(0.060)$ & $(0.089)$ & $(0.005)$ & $(0.012)$ & $(0.003)$ & $(0.003)$ \\
\hline \multirow[t]{2}{*}{$b r_{i t-1}$} & -0.012 & -0.016 & -0.020 & -0.013 & -0.012 & -0.025 & 0.022 \\
\hline & $(0.020)$ & $(0.020)$ & $(0.027)$ & $(0.059)$ & $(0.019)$ & $(0.027)$ & $(0.015)$ \\
\hline \multirow[t]{2}{*}{$Q_{i t-1}$} & $0.055^{* * *}$ & $0.044 * * *$ & $0.059 * * *$ & 0.007 & & 0.003 & 0.007 \\
\hline & $(0.005)$ & $(0.009)$ & $(0.015)$ & $(0.016)$ & & $(0.012)$ & $(0.010)$ \\
\hline \multirow[t]{2}{*}{$(P C / A)_{i t-1}$} & $-1.524 * * *$ & $-1.321 * * *$ & $-1.333 * *$ & & & & \\
\hline & $(0.149)$ & $(0.253)$ & $(0.146)$ & & & & \\
\hline \multirow{2}{*}{$\begin{array}{l}\text { Fundingdummy } \\
(P C / A)_{i t-1} \times\end{array}$} & & & & $-0.947 * * *$ & $-0.663 *$ & $5.009 * *$ & 3.340 \\
\hline & & & & $(0.058)$ & $(0.390)$ & $(2.307)$ & $(2.083)$ \\
\hline \multirow[t]{2}{*}{$(\text { Funding status } / A)_{i t-1}$} & & 0.343 & & & 1.072 & & \\
\hline & & $(0.438)$ & & & $(1.393)$ & & \\
\hline \multirow[t]{2}{*}{$(\text { Overfunding } / A)_{i t-1}$} & & & -1.005 & & & & \\
\hline & & & $(1.397)$ & & & & \\
\hline \multirow[t]{2}{*}{$(\text { Underfunding } / A)_{i t-1}$} & & & -0.188 & & & & \\
\hline & & & $(0.556)$ & & & & \\
\hline \multirow[t]{2}{*}{$T_{2005}$} & & & & & & & 0.029 \\
\hline & & & & & & & $(0.031)$ \\
\hline \multirow[t]{2}{*}{$\begin{array}{l}\text { Fundingdummy } \\
(P C / A)_{i t-1} \times T_{2005} \times\end{array}$} & & & & & & $-5.701 * * *$ & $-4.067 * *$ \\
\hline & & & & & & $(2.113)$ & (1.969) \\
\hline Y2003 (p-valuel) & $0.01 * * *$ & $0.07^{*}$ & 0.72 & 0.49 & 0.48 & $0.09^{*}$ & - \\
\hline Y2004 (p-valuel) & 0.30 & 0.77 & 0.94 & 0.19 & 0.52 & 0.44 & - \\
\hline Y2005 (p-valuel) & 0.71 & 0.92 & 0.81 & $0.09 *$ & 0.56 & 0.77 & - \\
\hline Y2006 (p-valuel) & 0.84 & 0.81 & 0.26 & 0.63 & 0.65 & 0.12 & - \\
\hline Number of firms & 180 & 179 & 179 & 174 & 174 & 174 & 174 \\
\hline No. of observations & 891 & 886 & 886 & 763 & 763 & 763 & 763 \\
\hline
\end{tabular}




\section{Table 5}

\section{Impact of New post-2005 Funding Requirements: Investment Equation}

The table presents the results for the two-step GMM-system estimation in a fixed effect panel data model using PcGive. Variables are scaled by end-of-year total book value of assets $(A)$ where applicable. $I$ is the firm's investment expenditure, $C F$ is cash flow, $c g r$ is capital gearing ratio, $b r$ is the borrowing ratio as in Nickell and Nicolitsas (1999), $Q$ is Tobin's $Q, S$ is total sales and $P C$ is the firm's pension contributions. $T_{2005}$ is a time dummy set to be 0 for observations before 2005 and 1 in and after 2005. Specifications (1) considers only the effect of pension contributions. In Specification (2) the pension funding status is used as a control for its correlation with unobserved investment opportunities. Specifications (3) the funding status control is underfunding and overfunding, separately. Specifications (4) to (6) use $T_{2005}$ and $T_{2005} \times(P C / A)_{i t-1}$ as the time and group controls in the regression. The sample data range from fiscal year 2000 to 2007 and p-values for the time dummies of year 2004 to 2007 are reported. Asymptotic robust stand errors are reported in parenthesis. *, **, *** stand for $10 \%, 5 \%$ and $1 \%$ significance levels, respectively. The regressions use both contemporary and lagged independent variables but only results for the latter are reported to save space.

\begin{tabular}{|c|c|c|c|c|c|c|c|}
\hline \multirow[b]{2}{*}{ Specifications } & \multicolumn{7}{|c|}{ Dependent variable: Investment $_{i t} / A_{i t}$} \\
\hline & (1) & (2) & (3) & (4) & (5) & (6) & (7) \\
\hline \multirow[t]{2}{*}{$(I / A)_{i t-1}$} & 0.082 & 0.099 & $0.172 *$ & 0.071 & $0.154 * *$ & $0.141 *$ & $0.142 *$ \\
\hline & $(0.076)$ & $(0.074)$ & $(0.090)$ & $(0.074)$ & $(0.074)$ & $(0.084)$ & $(0.080)$ \\
\hline \multirow[t]{2}{*}{$(I / A)_{i t-2}$} & -0.011 & -0.011 & 0.116 & -0.006 & 0.147 & 0.092 & 0.091 \\
\hline & $(0.075)$ & $(0.074)$ & $(0.089)$ & $(0.075)$ & $(0.095)$ & $(0.093)$ & $(0.096)$ \\
\hline \multirow[t]{2}{*}{$(S / A)_{i t-1}$} & $-0.044 * * *$ & $-0.038 * * *$ & -0.006 & $-0.043 * * *$ & -0.012 & $-0.036^{* * *}$ & $-0.039 * * *$ \\
\hline & $(0.011)$ & $(0.010)$ & $(0.011)$ & (0.009) & $(0.008)$ & $(0.008)$ & $(0.009)$ \\
\hline \multirow[t]{2}{*}{$(C F / A)_{i t-1}$} & -0.114 & -0.177 & -0.131 & -0.074 & 0.002 & $-0.214 * *$ & $-0.193^{*}$ \\
\hline & $(0.133)$ & $(0.137)$ & $(0.123)$ & $(0.139)$ & $(0.091)$ & $(0.106)$ & $(0.110)$ \\
\hline \multirow[t]{2}{*}{$c g r_{i t-1}$} & -0.003 & $-0.004 *$ & $-0.006^{* * *}$ & $-0.004^{*}$ & $-0.006 * *$ & -0.004 & -0.005 \\
\hline & $(0.002)$ & $(0.002)$ & $(0.002)$ & $(0.002)$ & $(0.002)$ & $(0.003)$ & $(0.003)$ \\
\hline \multirow[t]{2}{*}{$b r_{i t-1}$} & -0.001 & -0.001 & -0.001 & -0.002 & -0.002 & -0.002 & -0.002 \\
\hline & $(0.001)$ & $(0.002)$ & $(0.002)$ & $(0.002)$ & $(0.002)$ & $(0.003)$ & $(0.003)$ \\
\hline \multirow[t]{2}{*}{$Q_{i t-1}$} & $0.030 * * *$ & $0.030 * * *$ & 0.008 & $0.032 * * *$ & 0.009 & $0.023 * *$ & $0.027 * * *$ \\
\hline & $(0.007)$ & $(0.007)$ & $(0.006)$ & $(0.007)$ & $(0.006)$ & $(0.009)$ & $(0.010)$ \\
\hline \multirow[t]{2}{*}{$(P C / A)_{i t-1}$} & -0.197 & -0.204 & $-0.315^{* *}$ & & & & \\
\hline & $(0.162)$ & $(0.161)$ & $(0.132)$ & & & & \\
\hline \multirow{2}{*}{$\begin{array}{l}\text { Fundingdummy } y_{i t-1} \times \\
(P C / A)_{i t-1}\end{array}$} & & & & -0.296 & $-0.539 * *$ & $1.582 * * *$ & $1.475^{* *}$ \\
\hline & & & & $(0.217)$ & $(0.220)$ & $(0.535)$ & $(0.742)$ \\
\hline \multirow[t]{2}{*}{$(\text { Funding status } / A)_{i t-1}$} & & -0.040 & & & & & \\
\hline & & $(0.041)$ & & & & & \\
\hline \multirow[t]{2}{*}{$(\text { Overfunding } / A)_{i t-1}$} & & & 0.042 & & 0.033 & & \\
\hline & & & $(0.112)$ & & $(0.096)$ & & \\
\hline \multirow[t]{2}{*}{$(\text { Underfunding } / A)_{i t-1}$} & & & $0.153 * * *$ & & $0.131 * *$ & & \\
\hline & & & $(0.056)$ & & $(0.052)$ & & \\
\hline \multirow[t]{2}{*}{$T_{2005}$} & & & & & & & $0.059 * *$ \\
\hline & & & & & & & $(0.027)$ \\
\hline \multirow[t]{2}{*}{$\begin{array}{l}\text { Fundingdummy } \\
T_{2005} \times(P C / A)_{i t-1} \times\end{array}$} & & & & & & $-1.816^{* * *}$ & $-1.686^{* *}$ \\
\hline & & & & & & $(0.586)$ & $(0.795)$ \\
\hline Y2003 (p-valuel) & 0.92 & 0.22 & $0.02 * *$ & 0.79 & $0.06^{*}$ & 0.32 & - \\
\hline Y2004 (p-valuel) & 0.57 & $0.09 *$ & 0.38 & 0.54 & 0.64 & 0.78 & - \\
\hline Y2005 (p-valuel) & 0.41 & 0.68 & 0.13 & 0.65 & 0.19 & 0.11 & - \\
\hline Y2006 (p-valuel) & 0.60 & 0.54 & 0.65 & 0.39 & 0.91 & 0.22 & - \\
\hline Number of firms & 171 & 171 & 171 & 171 & 171 & 171 & 171 \\
\hline No. of observations & 700 & 700 & 700 & 698 & 698 & 698 & 698 \\
\hline
\end{tabular}


Figure 1: Pension contributions over time.

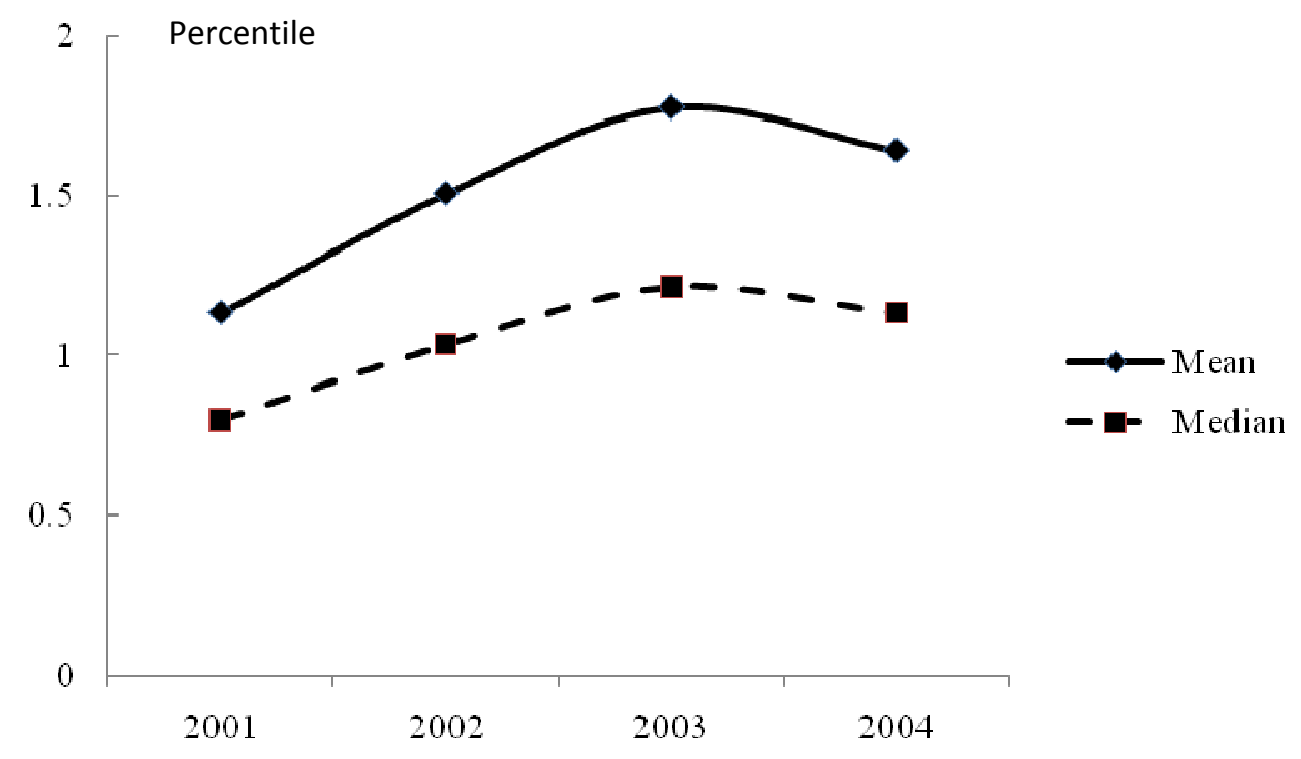

The graph reports the mean and the median values of pension contributions divided by total assets between 2001 and 2004 for all FTSE350 firms with defined benefit pension schemes. Both mean and median are expressed in percentage values.

Figure 2: Distribution of pension contributions as a percentage of assets.

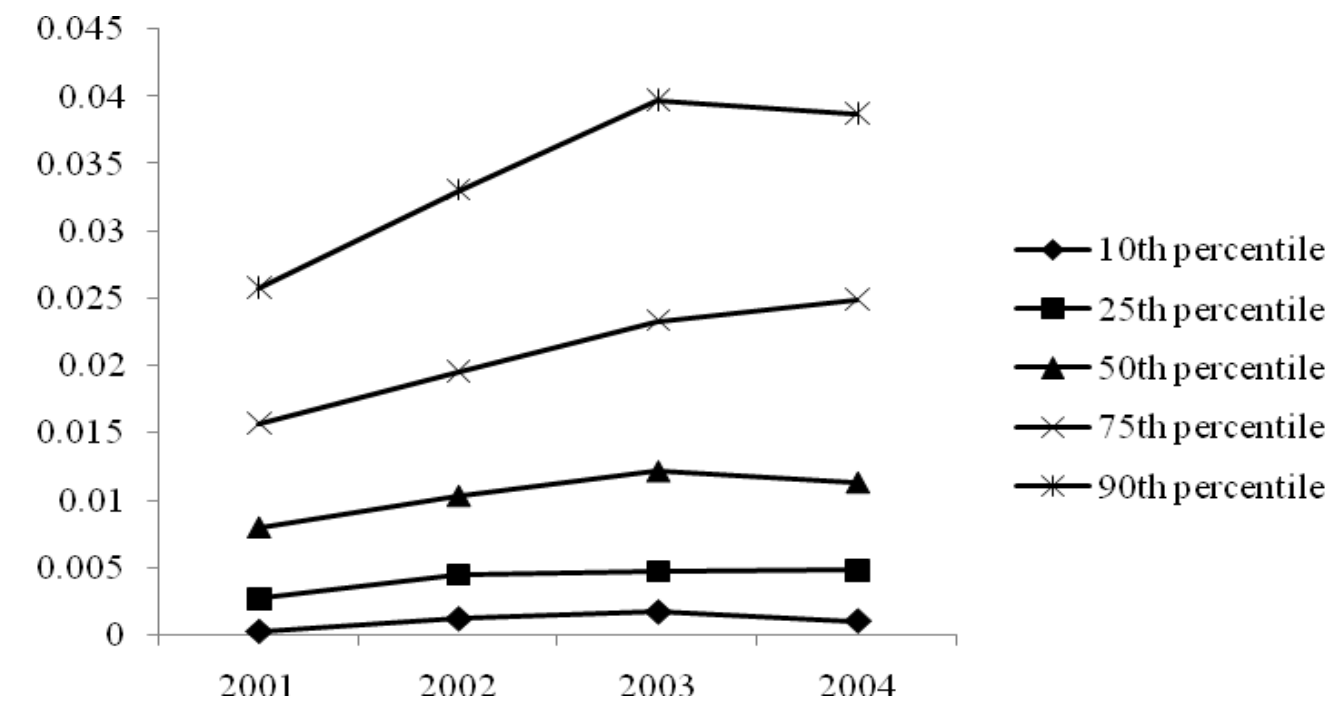

This chart shows the distribution of pension contributions as a percentage of assets on the 10th, 25th, 50th, 75th and 90th percentile levels, for all FTSE350 firms with defined benefit pension schemes. The percentiles are reported in real values. 


\section{Figure 3: Kernel regression of pension contributions on funding status.}

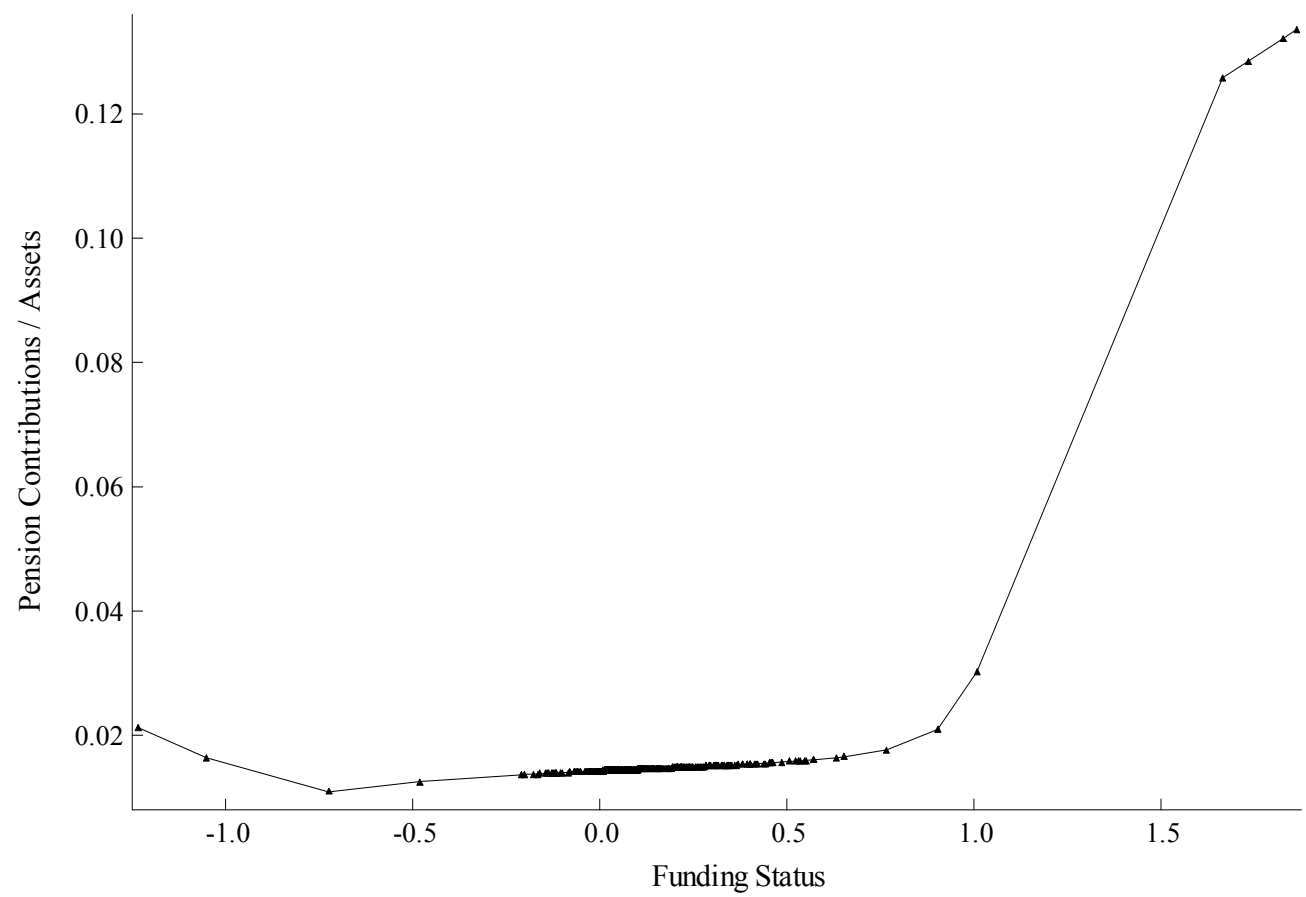

This graph reports the results for Epanechnikov kernel smoothing using pooled data of pension contributions and pension funding status for all FTSE350 firms with defined benefit pension schemes from 2001 to 2004. Funding status is calculated as the ratio of pension deficit to total assets therefore negative values stand for overfunded schemes and positive values for underfunded schemes.

\section{Figure 4: Composition of the assets and liabilities of DB pension schemes}

\begin{tabular}{l|l}
\hline \multicolumn{1}{c|}{ Pension Assets $(\boldsymbol{P A})$} & \multicolumn{1}{c}{ Pension Liabilities $(\boldsymbol{P L})$} \\
\hline Opening fair value of scheme assets & Opening DB pension liabilities \\
$(+)$ Return on the scheme assets $(R O A)$ & $(+)$ Pension service cost $(P S C)$ \\
$(+)$ Pension contributions $(P C)($ employer and & $(+)$ Pension interest cost $(P I C)$ \\
$\quad$ employee contributions) & $(+)$ Other cost \\
(-) Benefits paid & $(-)$ Benefits paid \\
Closing fair value of scheme assets & Closing DB pension liabilities \\
\hline
\end{tabular}

